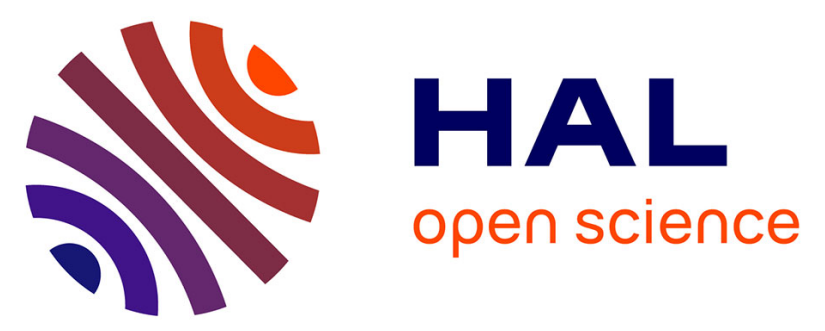

\title{
New Late Neolithic (c. 7000-5000 BC) archeointensity data from Syria. Reconstructing 9000years of archeomagnetic field intensity variations in the Middle East
}

Yves Gallet, Miquel Molist Montaña, Agnès Genevey, Xavier Clop Garcia, Erwan Thébault, Anna Gómez Bach, Maxime Le Goff, Béatrice Robert, Inga Nachasova

\section{- To cite this version:}

Yves Gallet, Miquel Molist Montaña, Agnès Genevey, Xavier Clop Garcia, Erwan Thébault, et al.. New Late Neolithic (c. 7000-5000 BC) archeointensity data from Syria. Reconstructing 9000years of archeomagnetic field intensity variations in the Middle East. Physics of the Earth and Planetary Interiors, 2015, 238, pp.89-103. 10.1016/j.pepi.2014.11.003 . hal-01096917

\section{HAL Id: hal-01096917 https: / hal.sorbonne-universite.fr/hal-01096917}

Submitted on 18 Dec 2014

HAL is a multi-disciplinary open access archive for the deposit and dissemination of scientific research documents, whether they are published or not. The documents may come from teaching and research institutions in France or abroad, or from public or private research centers.
L'archive ouverte pluridisciplinaire HAL, est destinée au dépôt et à la diffusion de documents scientifiques de niveau recherche, publiés ou non, émanant des établissements d'enseignement et de recherche français ou étrangers, des laboratoires publics ou privés. 


\section{ACCEPTED MANUSCRIPT}

1 New Late Neolithic (c.7000-5000 BC) archeointensity data from Syria.

2 Reconstructing 9000 years of archeomagnetic field intensity variations in the

3 Middle East

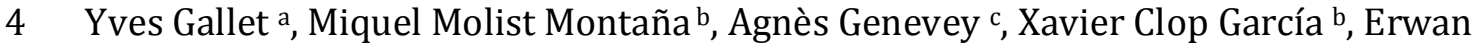

5 Thébault a,d , Anna Gómez Bach b, Maxime Le Goff a, Béatrice Robert e, Inga Nachasova f

6 a Institut de Physique du Globe de Paris, Sorbonne Paris Cité, Université Paris Diderot, UMR

77154 CNRS, F-75005 Paris, France

8 b SGR SAPPO. Prehistory Department, Facultat de Filosofia i Lletres, Edifici B, Universitat

9 Autònoma de Barcelona 08193 Bellaterra, Barcelona, Spain

10 c UPMC Université Paris 06, UMR CNRS 8220, Laboratoire d'Archéologie Moléculaire et 11 Structurale, LAMS, F-75005 Paris, France

$12 \mathrm{~d}$ LPG, UMR CNRS 6112, Laboratoire de Planétologie et Géodynamique de Nantes, 13 Université de Nantes, 44322 Nantes cedex 03, France

14 e Université Lumière - Lyon 2, UMR CNRS 5133 ArchéOrient, Lyon, France

15 Institute of Physics of the Earth, Russian Academy of Science, Moscow, Russia

Keywords: Archeomagnetism, Geomagnetic field intensity, Neolithic, Halaf, Middle East,

Holocene

\section{ABSTRACT}

We present new archeomagnetic intensity data from two Late Neolithic archeological sites (Tell Halula and Tell Masaïkh) in Syria. These data, from 24 groups of potsherds encompassing 15 different time levels, are obtained using the Triaxe experimental protocol, which takes into account both the thermoremanent magnetization anisotropy and cooling rate effects on intensity determinations. They allow us to recover the geomagnetic intensity variations in the Middle East, between $\sim 7000 \mathrm{BC}$ and $\sim 5000 \mathrm{BC}$, i.e. during the so-called pre-Halaf, proto-Halaf, Halaf and Halaf-Ubaid Transitional cultural phases. The data are compared with previous archeointensity results of similar ages from Northern Iraq (Yarim Tepe II and Tell Sotto) and Bulgaria. We find that previous dating of the Iraqi material was in error. When corrected, all northern Mesopotamian data show a relatively good consistency and also reasonably match with the Bulgarian archeointensity dataset. Using a compilation of available data, we construct a geomagnetic field intensity variation curve for the Middle East encompassing the past 9000 years, which makes it presently the longest known regional 
37 in dipole field moment over most of the Holocene. In particular, we discuss the 38 possibility that a significant dipole moment maximum occurred during the third millennium BC, which cannot easily be identified in available time-varying global geomagnetic field reconstructions.

\section{Introduction}

Recent studies have been focused on the construction of time-varying global archeomagnetic field models that cover most of the Holocene (e.g. Korte et al., 2011; Nilsson et al., 2014; Pavón-Carrasco et al., 2014). These models have been developed with the aim to decipher core dynamics over centennial and millennial time scales, the evolution of the past solar activity and the interactions between geomagnetic field and external processes (e.g. Korte et al., 2009; Licht et al., 2013; Usoskin et al., 2014). In all these studies, however, the authors acknowledge the fact that for the more ancient periods, i.e. beyond the first millennium BC, the reliability and accuracy of the geomagnetic field models are strongly penalized by the low number and the poor temporal and geographical distributions of the available archeomagnetic and volcanic paleomagnetic data. To overcome this problem, often paleomagnetic data from sediments have been included in the models reference dataset; nevertheless sedimentary data do not significantly improve the accuracy of the models because a part of them, difficult to estimate, may be biased by experimental errors and/or because these data often lack precise dating (e.g. Valet et al., 2008; Nilsson et al., 2010). There is therefore a critical need for new well dated archeomagnetic data dated with ages older than the first millennium BC.

The Middle East, thanks to its rich archeological and historical heritage, offers the possibility to travel back through the geomagnetic field history over most of the Holocene, recovering what could be the longest known archeomagnetic field record. Archeomagnetic studies conducted up to now were mainly focused on the Bronze and Iron Age archeological periods, allowing a better characterization of the regional geomagnetic field intensity behavior for the last 3 millennia BC (i.e. Genevey et al., 2003; Gallet and Le Goff, 2006; Gallet et al., 2008, 2014; Ben-Yosef et al., 2008, 2009; Gallet and Al Maqdissi, 2010; Thébault and Gallet, 2010; Shaar et al., 2011; Ertepinar et al., 2012; Gallet and Butterlin, 2014). These studies have revealed significant field intensity 
variations, and in particular a series of intensity maxima between $\sim 2600$ and $2500 \mathrm{BC}$, between $\sim 2300-2000 \mathrm{BC}$, around $1500 \mathrm{BC}$ and at the very beginning of the first millennium BC (e.g. Gallet et al., 2014). These studies have further shown that the beginning of the first millennium BC was most probably marked by the highest geomagnetic field intensity so far detected during the Holocene and perhaps even before (Ben-Yosef et al., 2009; Shaar et al., 2011; Ertepinar et al., 2012; Livermore et al., 2014).

In contrast, for older periods between $\sim 7000 \mathrm{BC}$ and $3000 \mathrm{BC}$, i.e. during the Late Neolithic (or Pottery Neolithic) and the Chalcolithic, the archeointensity data from the Middle East remain relatively scarce, which prevents an accurate description of the regional geomagnetic field intensity variations (e.g. Genevey et al., 2003; Ben-Yosef et al., 2008). However, several possibilities exist to sample pre-Bronze Age archeological sites. This is particularly true for the 6th millennium BC, which saw the development of the Halaf culture throughout the northern Mesopotamian region. This culture was named after the Tell Halaf archeological site in northern Syria (Fig. 1a), which was discovered and first excavated by the German diplomat Max von Oppenheim at the beginning of the 20th century. The Halaf culture is notably characterized by a plentiful pottery production presenting a fine and light-colored clay paste, with brown or black monochrome or polychromatic painted decorations (e.g. Akkermans and Schwartz, 2003; Nieuwenhuyse et al., 2013 and references therein). This well-fired ceramic production thus constitutes a promising target for archeointensity investigations.

Going further back in time, archeomagnetic studies may benefit from recent archeological studies conducted in Syria that focused on the 7th millennium BC, which saw the emergence of the first pottery production in the Near East (e.g. Tsuneki and Miyake, 1996; Le Mière and Picon, 1998; Nishiaki and Le Mière, 2005; Molist et al., 2007; Nieuwenhuyse et al., 2010, 2013). At first rare, the pottery was sometimes of a surprisingly elaborated conception with a painted decoration during a primitive phase referred to as the "Initial Pottery Neolithic" ( 7000-6700 BC; e.g. Van der Plicht et al., 2011). By the middle of the 7th millennium BC, the use of ceramics spread over northern Mesopotamia (Nieuwenhuyse et al., 2010, 2013 and references therein). This pre-Halaf period is mainly represented by undecorated plant-tempered pottery with a coarse clay paste shaped into baskets. The fineness of the clay paste improved at the end of the 7th millennium BC during a period referred to as proto-Halaf ( $\sim 6050-5900 \mathrm{BC})$, just 
101 preceding the Halaf period, with the use of mineral-tempered clay (e.g. Cruells and 102 Nieuwenhuyse, 2004). According to Akkermans and Schwarz (2003), the pre-Halaf 103 coarse pottery was produced in open fires, with heating temperatures of about 700$104750^{\circ} \mathrm{C}$, while the elaborate Halaf ceramics were most probably heated at higher 105 temperatures in chambered kilns. For the pre- and proto-Halaf periods encompassing 106 the 7th millennium BC, archeointensity studies are thus still possible, but they may be 107 further complicated by the characteristics of the ceramic production.

To extend the Syrian geomagnetic field intensity record, which presently mainly 109 documents the Bronze and Iron Age periods, we conducted an archeomagnetic study on 111 time interval of nearly two millennia ( $\sim 7000$ to $\sim 5000$ BC) covering the Pottery 112 Neolithic, at the end of the Neolithic (e.g. Campbell, 2007; Campbell and Fletcher, 2010; 113 Van der Plicht et al., 2011; Nieuwenhuyse et al., 2013 and references therein). The new 114 archeointensity data reported in this study were mostly obtained from potsherds 115 collected from the archeological site of Tell Halula located in northern Syria (Fig. 1a). 116 These results were complemented by few data obtained from potsherds discovered at 117 the archeological site of Tell Masaïkh, located south-east along the middle course of the 118 Euphrates river (Fig. 1a). It is of interest to note that the longest and almost continuous 119 regional archeointensity record presently available was obtained from Bulgaria 120 (Kovacheva et al., 2014). It begins around 6000 BC, i.e. a date during the proto-Halaf 121 period, which means that some of the new data presented in this study are the oldest 122 archeointensity data recovered until now. Furthermore, we recall the recent effort of 123 data compilation of archeomagnetic, volcanic and sedimentary paleomagnetic results 124 that led to the construction of global archeomagnetic field models encompassing almost 125 the entire Holocene (Korte et al., 2011; Nilsson et al., 2014; Pavón-Carrasco et al., 2014). 126 Any new archeomagnetic intensity data dated to the Late Neolithic-Early Chalcolithic 127 period, now rather rare (e.g. Genevey et al., 2008; Knudsen et al., 2008), will therefore 128 allow us to test, at least regionally, the accuracy of the available models and in return 129 will better constrain these models. This point is particularly critical and we will also 130 report in this study on erroneous dating of a relatively large archeointensity dataset 131 previously obtained in the Middle East for the $7^{\text {th }}$ and $6^{\text {th }}$ millennia BC (Nachasova and 132 Burakov, 1995, 1998). 


\section{Archeomagnetic sampling}

135

136

137

138

139

140

141

142

143

144

145

146

147

148

149

150

151

152

153

154

155

156

157

158

159

160

161

162

163

\subsection{Tell Halula}

Tell Halula $\left(\lambda=36^{\circ} 25^{\prime} \mathrm{N}, \varphi=38^{\circ} 10^{\prime} \mathrm{E}\right)$ is located in the modern Syrian administrative province of Raqqa, about $80 \mathrm{~km}$ west of the city of Raqqa and $85 \mathrm{~km}$ east of the city of Aleppo. This archeological site, $\sim 4 \mathrm{~km}$ west of the Euphrates, forms a subcircular artificial mound (360 m x $300 \mathrm{~m}$ ), with an archeological deposit thickness of 14 m (Fig. 1b). Archeological excavations conducted since 1991 by a team of the Universitat Autónoma de Barcelona revealed a total of 38 phases of occupation. From the stratigraphic and archeological constraints (including chipped stone artefacts, pottery typology, figurines and architecture), it has been determined that the site was occupied continuously from the Middle Pre-Pottery Neolithic B (PPNB) to the Late Halaf periods, i.e. from $\sim 7800$ to 5300 cal BC (Molist et al. 2007, 2013; Molist 1996, 2001). The systematic archeological fieldwork at Tell Halula has brought significant knowledge about the development of farming, especially in the final stages of the Neolithisation process, when economic, technological and cultural changes were being consolidated.

The different phases of human occupation have been recovered in several sectors, especially in the south, south-east and central parts of the settlement (Sectors 1, $2,7,14,30,44$ and 45). The Neolithic ceramic horizon encompasses most of the seventh millennium BC and part of the sixth millennium BC (Architectural Phases 20 to 38), spanning the pre-Halaf (or Period 5 according to Lyon's School terminology; Hours et al., 1994), the proto-Halaf or Halaf Transitional and the Halaf (Early, Middle, Late) periods. The archeological and stratigraphic data indicate the presence of a sedentary population, with several large houses or architectural structures relatively dispersed over a surface of $\sim 6$ ha, i.e. with large open areas between households and buildings for domestic use. Furthermore, several structures for a collective use were discovered for the pre-Halaf period, with a massive enclosing wall in Sector 1 and a drainage channel in Sector SS7 (Molist, 1996, 1998; Molist and Faura, 1999; Molist et al., 2013).

The pottery assemblages analyzed in the present study were sampled following the main chronocultural phases documented at Tell Halula (Fig. 2; see description in Molist et al., 2013 and Supplementary Text1). Here, we used the same chronological 
164 time scale as in Molist et al. (2013). For the first pottery production within the Early Pre-

165 Halaf (Ceramic Phase I; 7000-6600 BC), two groups of fragments collected from the 166 top of Sector 2 were analyzed. The first group of fragments (SY 127) was recovered from 167 a pit located in an open area and the second (SY 125), a little younger than the previous 168 one, was collected from an occupation level associated with a rectangular building. For 169 the intermediate pre-Halaf period (Ceramic Phase II; 6600-6300 BC), three pottery 170 groups were collected from a large outdoor space between several domestic units. Their 171 age assignment was established via stratigraphy, with the group of potsherds SY96 172 being the most recent, SY97-129 intermediate and SY98-128 being the oldest. Finally, 173 pottery group SY130, comprising pottery fragments found in a pit from Sector 49, comes 174 from the late pre-Halaf (Ceramic Phase III; 6300-6050 BC).

$175 \quad$ For the period referred to as proto-Halaf ( 6050-5900 BC), corresponding to 176 Ceramic Phase IV defined at Tell Halula, two pottery groups of household artifacts were 177 collected in Sectors 44 (SY94-137) and 40 (SY95). A single group (SY91) lies within the 178 Early Halaf period (Ceramic Phase V; 5900-5750 BC), which was recovered from a 179 multicellular house located in sector 44. Different pits discovered in the same area of 180 Sector 45 yielded four contemporaneous groups of pottery (SY87, SY88, SY89, SY90) 181 dated within the Middle Halaf period (Ceramic Phase VI; 5750-5550 BC).

$182 \quad$ Nine groups of fragments were collected from the most recent chronological 183 phases at Tell Halula dated in the Late Halaf (Ceramic Phase VII; 5550-5300 BC). This 184 relatively dense sampling was possible due to a relatively complete stratigraphic 185 sequence from Sector 49 (Gómez, 2011). For most of these groups, the fragments were 186 recovered from different pits excavated in a large open yard, that were used for the 187 disposal of ash and domestic waste. The stratigraphic data and the ceramic typology 188 distinguish five successive temporal intervals, each being documented by one or several 189 pottery groups (from older to younger: SY86-131; SY135; SY84 and SY138; SY82 and 190 SY83-136; SY80, SY81 and SY132).

In summary, 22 different pottery groups from 14 successive occupation levels 192 were thus sampled at Tell Halula, whose dates span $\sim 1700$ years, between $\sim 7000$ and $193 \sim 5300$ BC. For displaying the results in a relative chronological framework for phases II 194 and VII, we made the rough approximation of an equi-temporal distribution for 195 respectively the three and five successive occupation levels (i.e. assuming a duration of 
196100 years for each intermediate pre-Halaf level between $6600 \mathrm{BC}$ and $6300 \mathrm{BC}$ and a

197 duration of 50 years for each Late Halaf level between 5550 BC and 5300 BC; dating 198 with * in Table 1).

\subsection{Tell Masaïkh}

201

The archeological site of Tell Masaïh $\left(\lambda=34^{\circ} 25^{\prime} \mathrm{N}, \varphi=40^{\circ} 01^{\prime} \mathrm{E}\right)$ is located on a river terrace in the middle Euphrates Valley (left bank), in the modern province of Deir ez-Zor (eastern Syria). Discovered in 1996 by the Mission Archéologique Française de Ashara/Terqa led by 0. Rouault, excavations at Tell Masaïkh ( $\sim 4 \mathrm{~km}$ from Terqa), conducted under the leadership of M.-G. Masetti-Rouault, have revealed several phases of occupation starting with the Late Neolithic (Halaf). More recent periods include significant Neo-Assyrian remains, with a citadel and a palace dated in the $9^{\text {th }}-8^{\text {th }}$ centuries BC (Iron Age period), which led the identification of Tell Masaïkh as the Assyrian city named Kar-Assurnasirpal (see general discussion in Masetti-Rouault, 2010).

The discovery in the western sector D of Tell Masaïkh of an artisanal Halaf settlement makes this site also quite unique. It is located away from most other known

213 Halaf archeological sites situated more to the North with rainfall above $250 \mathrm{~mm} / \mathrm{year}$ 214 (while rainfall is below this isohyet in the Tell Masaïkh region; e.g. Masetti-Rouault, 2006; Robert, 2010), which opens discussion on farming systems and on the use of irrigation at this time.

Excavations of the Halaf levels at Tell Masaïkh unearthed several occupation levels in open areas with fire places (tannurs), several kilns probably for pottery production and a $1.5 \mathrm{~m}$-thick, $\sim 20 \mathrm{~m}$-long stone wall that supported a terrace. A rich ensemble of Late Halaf potsherds was also recovered. The potsherds analyzed in the

221 present study were found in the uppermost layers dated in the Halaf-Ubaid Transitional 222 ( 5300-5000 BC; e.g. Campbell and Fletcher, 2010) based on their typology and from 223 the painted decoration that used manganese pigments for black color. The youngest

224 Halaf pottery belongs to polychrome Late Halaf types associated with some Impressed 225 Ware known as Dalma types and Ubaid-style ceramics (Masetti-Rouault, 2005; Robert et 226 al., 2008; Robert, 2010). We sampled in Locus K171 two groups of these fragments with 
227 fine mineral-tempered clay paste (pottery groups SY37, SY38), the first in the 228 occupation layer referred to as E2, and the second on floor E7 on top of layer E2.

\section{New archeomagnetic intensity results}

All the archeointensity measurements reported in this study were obtained using the experimental protocol developed by Le Goff and Gallet (2004) for the Triaxe magnetometer. The details of this experimental protocol can be found in Le Goff and Gallet (2004) (see also Genevey et al., 2009; 2013; Hartmann et al., 2010; Gallet et al., 2014). We only recall here that it relies on magnetization measurements of a small specimen $\left(<1 \mathrm{~cm}^{3}\right)$ directly carried out at high temperatures and on a sequence of measurements (with successive heating and cooling cycles) automatically performed over a fixed temperature range between a low temperature referred to as $\mathrm{T}_{1}$ (typically of $150^{\circ} \mathrm{C}$ ) and a high temperature referred to as $\mathrm{T}_{2}$ (typically between $500^{\circ} \mathrm{C}$ and $530^{\circ} \mathrm{C}$ ). In the past few years, a relatively large collection of archeointensity data of different ages and of different origins was obtained using the Triaxe, and comparative studies

242 with results derived from more classical methods (i.e. from the Thellier and Thellier's 243 (1959) method as revised by Coe (1967) or from the IZZI version of Thellier and 244 Thellier's (1959) method; e.g. Yu et al., 2004) demonstrated the reliability of the Triaxe 245 intensity data when quality criteria are taken into account. In our study, we use the 246 same quality criteria relative to the intensity determination for a specimen as those 247 described by Genevey et al. (2009) and Hartmann et al. (2010, 2011), and which were 248 also used more recently by Genevey et al. (2013), Gallet et al. (2014) and Gallet and 249 Butterlin (2014) (Supplementary Table 1). In particular, these criteria allow us to

250 eliminate the data that could be biased due to alteration of the magnetic minerals during 251 heating. Moreover, the temperature range over which the intensity determinations are 252 recovered from each specimen is precisely adjusted so that the analyzed magnetization 253 component is univectorial and corresponds to the magnetization acquired during the 254 manufacture of the pottery. Fig. 3 shows two examples of demagnetization behaviors. 255 After the removal of the viscous low-temperature component, the first behavior shows a 256 single magnetization component above $\sim 200^{\circ} \mathrm{C}$ (SY89-08), while the second behavior 257 reveals two components (SY140-06). In these cases, the temperature range was 258 adjusted above $\sim 200^{\circ} \mathrm{C}$ and $\sim 340^{\circ} \mathrm{C}$, respectively for obtaining intensity determinations 
259

260

261

262

263

264

265

266

267

268

269

270

271

272

273

274

275

276

277

278

279

280

281

282

283

284

285

286

287

288

289

290

at the specimen level. Finally, the intensity data should not be affected by the presence of multidomain magnetite grains and they take into account both the thermoremanent magnetization (TRM) anisotropy and cooling rate effects on TRM acquisition (for a thorough discussion on these aspects, see for instance in Le Goff and Gallet, 2004; Genevey et al., 2008, 2009; Hartmann et al., 2010).

Our archeointensity analyses were complemented by hysteresis measurements and by isothermal remanent magnetization (IRM) acquisition up to $0.8 \mathrm{~T}$ performed at Saint Maur using a laboratory-built inductometer coupled with an electro-magnet. In most cases, two fragments were analyzed for each group of fragments. IRM measurements show very similar behaviors with saturation reached in relatively low magnetic fields ( 0.2-0.3 T), indicating the absence of high-coercivity minerals (Fig. $4 \mathrm{a}$ ). We note that the hysteresis loops are generally not constricted (Fig. 4b-c). Thermomagnetic low-field susceptibility curves obtained using a KLY-3 Kappabridge coupled with a CS3 thermal unit show that the existing magnetic grains have maximum unblocking temperatures below $600^{\circ} \mathrm{C}$ (Fig. $4 \mathrm{~d}-\mathrm{g}$ ). All these magnetic properties indicate that the magnetization of our specimens is most probably predominantly carried by minerals of the (titano)magnetite family. Furthermore, the thermomagnetic curves exhibit variable behaviors, independently of the age of the fragments, which suggests the presence of (titano)magnetite with different titanium contents or different grain sizes. We also observe a good reversibility between the heating and cooling susceptibility vs. temperature curves, which constitutes a good marker of the stability of the magnetic mineralogy on heating. We note that these magnetic properties are very similar to those we previously obtained from Syrian fired-clay artifacts of younger ages (e.g. Genevey et al., 2003; Gallet et al., 2008; 2014; Gallet and Butterlin, 2014).

Except for one case, the hysteresis parameters obtained for the fragments from Tell Halula lie within the pseudo-single domain (PSD) range of magnetite defined by Dunlop et al. (2002a) when projected on a Day plot (Day et al., 1977). Most $\mathrm{M}_{\mathrm{RS}} / \mathrm{M}_{\mathrm{S}}$ and $\mathrm{H}_{\mathrm{CR}} / \mathrm{H}_{\mathrm{C}}$ ratios are concentrated inside a restricted area, with $\sim 0.30>\mathrm{M}_{\mathrm{RS}} / \mathrm{M}_{\mathrm{S}}>\sim 0.15$ and $\sim 4>\mathrm{H}_{\mathrm{CR}} / \mathrm{H}_{\mathrm{C}}>\sim 2.5$ ), above the theoretical mixing curves for mixture of $\mathrm{SD}$ and $\mathrm{MD}$ magnetite grains but also well below the mixing curve of SD and superparamagentic (SP) magnetite grains (Fig. 4h). According to Dunlop (2002b), this may reflect a large distribution of grain sizes, including SP, SD and MD magnetite grains. In contrast, most 
291 of the hysteresis parameters obtained from Tell Masaïkh (open blue triangles in Fig. 4h)

292 fall within the theoretical SD-MD mixing curves defined by Dunlop (2002a), therefore 293 indicating a coarser grain size distribution for those specimens. It is worth mentioning 294 that the evolution of the techniques (preparation of the clay paste, firing conditions) 295 used to produce ceramics at Tell Halula between the pre-Halaf and Halaf periods is 296 clearly not reflected in the hysteresis ratios, their dispersions being very similar 297 regardless of the age of the fragments (colored symbols in Fig. 4h). Further considering 298 the data from Tell Masaïkh and the previous ones obtained from Ebla/Tell Mardikh 299 (grey dots in Fig. 4h; Gallet et al., 2014), it appears that the distribution of the hysteresis 300 parameters obtained at a given archeological site constitutes a magnetic signature of the 301 clay source used to produce pottery at this site, and it may be used as an identification 302 tool complementary to more classical chemical analyses.

303 Fig. 5 shows the intensity results obtained from eight pottery groups. Each curve 304 from each panel shown in this figure exhibits the intensity data obtained for one 305 specimen over a temperature range often exceeding $200-250^{\circ} \mathrm{C}$. In general, we only analyzed one specimen per fragment. However, when the number of favorable fragments was $\leq 5$ (i.e. for pottery groups SY127, SY125, SY95, SY38), we analyzed three specimens from each fragment and we first estimated a mean intensity value at the fragment level before computing a mean value at the group level. The success rate of our archeointensity analyses significantly varies according to the archeological periods. 311 While it is only $36 \%$ for the pre-Halaf period (54 fragments from 151 analyzed 312 fragments) and $56 \%$ (22 from 39 fragments) for the proto-Halaf period, it increases up 313 to $70 \%$ for the sites dated in the Halaf period (133 from 191 fragments) and 67\% for the 314 Halaf-Ubaid Transitional period (16 favorable fragments from 24 studied fragments). 315 The relatively low success rate for the pre-Halaf fragments is mainly due to the presence of two magnetization components, which is likely related to the use of these ceramics for 317 cooking (hence preventing in many cases the clear isolation of a primary 318 magnetization). Examples of failed results are reported in Supplementary Fig. 1. Overall, 319 we analyzed a total of 405 fragments, among which 225 fragments (254 specimens) 320 yielded favorable archeointensity results, allowing us to determine 24 mean intensity 321 values at the pottery group level. Results obtained at the specimen/fragment level are 322 detailed in Supplementary Table 2, while Table 1 provides the group-mean intensity 323 values. These intensity values are generally well defined, with a number of fragments 
324 analyzed per site larger or equal to 7 for 19 pottery groups ( $\geq 10$ for 10 sites) and a 325 standard deviation always of less than $5 \mu \mathrm{T}$, ranging between $1.8 \%$ and $11.4 \%$ of the 326 corresponding group-mean intensity values $(\leq 5.0 \%$ for 10 sites and $\leq 7.5 \%$ for 21 327 among the 24 studied pottery groups). We note, however, that the mean intensity value 328 obtained for group SY125 ( $6650-6550$ BC) is only defined by two fragments (6 329 specimens), but it was kept for the discussion below because of the scarcity of such old 330 archeointensity data.

\section{Late Neolithic archeointensity variations in the Middle East}

The new archeointensity data are reported in Fig. 6 (see also Supplementary Fig. 2 , where the results are averaged over the successive occupation levels). The new results show that the time interval between $\sim 7000 \mathrm{BC}$ and $\sim 5000 \mathrm{BC}$ was apparently marked in the Middle East by an overall decreasing trend in geomagnetic field intensity.

337 This decrease was however not regular. In particular, a relative intensity minimum is observed at the beginning of the Late Halaf period (pottery group SY86-131 with 20 favorable fragments), around the middle of the 6th millennium BC. An intensity peak appears to have occurred during the Late Halaf period, between $\sim 5550$ and $\sim 5300 \mathrm{BC}$. This intensity peak is supported by the low geomagnetic field intensity values obtained at Tell Masaïh for the Halaf-Ubaid Transitional period.

We compared the new Tell Halula and Tell Masaïkh data with two other archeointensity datasets of the same age previously obtained in relatively nearby regions (Fig. 7). The first dataset includes results obtained at Yarim Tepe II and Tell

346 Sotto, two multi-level archeological sites from northern Iraq (Fig. 1a; Nachasova and 347 Burakov, 1995, 1998). In these two studies, the pottery fragments were selected and 348 dated according to their stratigraphic position within a sequence of archeological deposits (with a total thickness of $780 \mathrm{~cm}$ at Yarim Tepe II and $280 \mathrm{~cm}$ at Tell Sotto), and assuming a constant accumulation rate of archeological deposits. Although such a sampling procedure may obviously introduce large uncertainties in the dating of the studied fragments, it nevertheless appears that this approach can provide satisfactory

353 results (e.g. Nachasova and Burakov, 1998; Kostadinova-Avramova et al., 2014). 354 However, in both cases, the dating considered by Nachasova and Burakov $(1995,1998)$ 
appears systematically shifted by several centuries relative to the most recent chronological Pottery Neolithic time scale (see Campbell, 2007; Bernbeck and Nieuwenhuyse, 2013). Indeed, the fragments from Yarim Tepe II are unambiguously archeologically dated to the Middle-Late Halaf period ( 5750-5300 BC; e.g., Campbell, 2007; Robert, 2009; Bernbeck and Nieuwenhuyse, 2013 and references therein), but their ages were mostly assigned in the 5th millennium BC. Similarly, the fragments collected at Tell Sotto were dated to the middle of the 6th millennium BC by Nachasova and Burakov (1998), but the studied ceramics are dated to the Late Pre-Halaf (Late proto-Hassuna and Archaic Hassuna cultural phases), i.e. between $\sim 6400$ and $\sim 6050$ BC (e.g. Bader, 1989; Bader and Le Mière, 2013; Le Mière pers. comm. 2014).

For these reasons, we assigned new ages to Yarim Tepe II and Tell Sotto considering first, the stratigraphic position of the concerned fragments as provided by the authors and second, assuming that the entire Middle-Late Halaf and Late Pre-Halaf periods were represented in the Yarim Tepe II and Tell Sotto deposits (like the authors considered but for two other time intervals). Finally, for displaying in Fig. 7a the data obtained at Yarim Tepe II, with only a single specimen studied per fragment, and at Tell Sotto we also performed intensity averaging over several fragments when the latter come from the same stratigraphic intervals, i.e. each time there was a group of fragments considered of the same age. We observe an overall good agreement with the data obtained at Tell Halula and Tell Masaïkh. In particular, this agreement confirms the occurrence in northern Mesopotamia of a relative intensity minimum around the middle of the 6th millennium $\mathrm{BC}$, which further strengthens the occurrence of an intensity peak at the beginning of the second half of the 6th millennium BC.

The second archeointensity dataset comprises the results encompassing the 6th millennium BC from Bulgaria that were recently updated by Kovacheva et al. (2014) (Fig. 7b). From this new analysis, a century-scale intensity peak seems to be emerging around the middle of the $6^{\text {th }}$ millennium, which might coincide, within age uncertainties, with that observed from the Syrian Late Halaf data. According to this interpretation, the data available for the Halaf-Ubaid Transitional period would come prior to the geomagnetic field intensity increase observed in the Bulgarian data at the end of the $6^{\text {th }}$ millennium BC. Constraining further this preliminary correlation will require the acquisition of new archeointensity data in the Balkans and in the Middle East. 


\section{Discussion}

389

390

391

392

393

394

395

396

397

398

399

400

401

402

403

404

405

406

407

408

409

410

411

412

413

414

415

416

417

418

We have undertaken the construction of a geomagnetic field intensity secular variation curve in the Middle East during the Holocene. For this purpose, we selected all the archeointensity data available inside a circle with a radius $1000 \mathrm{~km}$ around the archeological site of Tell Halaf $\left(\lambda=36^{\circ} 49^{\prime} \mathrm{N}, \varphi=40^{\circ} 02^{\prime} \mathrm{E}\right.$; Supplementary Fig. 3). The data were retrieved from the ArcheoInt database (Genevey et al., 2008) and complemented with the more recent studies (Ben-Yosef et al., 2009; Gallet and Al Maqdissi, 2010; Shaar et al., 2011, 2014; Ertepinar et al., 2012; Gallet et al., 2014; Gallet and Butterlin, 2014). They were obtained from the eastern part of Turkey, Cyprus, Syria, the Levant, Iraq, from the western part of Iran and from the Caucasus. Note that the large dataset from the Balkans and Greece (e.g. De Marco et al., 2008; Tema and Kondopoulou, 2011; Kovacheva et al., 2014) has not been included to allow it to be compared to different regional secular variation behaviors from elsewhere (e.g. between the Middle East, Eastern Europe and Western Europe). Genevey et al. (2008) proposed a set of selection criteria in order to distinguish between all available data those that meet minimum quality criteria. This approach enabled the construction of two datasets referred to as "Selected data" and "All data" in Genevey et al. (2008). Hereafter we have considered the compilation of selected data to calculate the Middle East geomagnetic field intensity variation curve, considering the new dating we estimated for Tell Sotto and Yarim Tepe II and using, for these two sites, the mean intensity values computed from fragments associated with the same stratigraphic level (Fig. 7a).

To calculate our curve, we first applied a method based on the use of sliding windows of 200 years successively shifted by 10 years through the past 9 millennia. We computed VADM values only for those time intervals containing at least 3 results. Following Thébaut and Gallet (2010) and Licht et al. (2013), we also used the bootstrap technique with 1000 runs by introducing random noise in the data within their experimental and age uncertainties. This allowed us to compute 1000 intensity variation curves. In Fig. 8a we displayed the averaged VADM (thick line) together with the minimum and maximum VADM values obtained for the different sliding windows, hence defining an envelope of equally possible VADM values. Due to the insufficient number of archeointensity data spanning the 5 th and 4 th millennia $\mathrm{BC}$, no averaged curve could be 
419 determined between $\sim 4930$ BC and $\sim 3650$ BC, i.e. during the Ubaid and Uruk periods in 420 Mesopotamia. This time interval therefore constitutes a particularly important target for 421 future archeomagnetic studies in the Middle East. For other periods, the computed curve 422 appears very consistent with almost all the Syrian data (blue dots in Fig. 8a; Genevey et 423 al., 2003; Gallet and Le Goff, 2006; Gallet et al., 2006, 2008, 2014; Gallet and Al Maqdissi, 424 2010; Gallet and Butterlin, 2014 and this study). We observe the same variation trends, 425 with distinct intensity maxima during the second half of the first millennium $\mathrm{AD}$, at the 426 beginning of the first millennium $\mathrm{BC}$ and around the middle of the third millennium $\mathrm{BC}$. 427 Supplementary Fig. 4 also exhibits the averaged intensity curve computed without the 428 Syrian data, showing in particular that the latter data set allows us to better constrain 429 the curve during the third millennium BC (note that this curve takes into account the 430 new dating of the Tell Sotto and Yarim Tepe II data). The temporal resolution of 200 431 years of the regional averaged curve most probably prevents the recovery of distinct century-scale intensity (VADM) maxima at $\sim 1500$ BC, $\sim 2550$ BC and $\sim 2300$ BC clearly observed from Syrian data at Ebla and Mari (Gallet et al., 2008, 2014; Gallet and 434 Butterlin, 2014), as well as the maximum in intensity between $\sim 5500$ and $\sim 5300$ BC 435 exhibited by the Tell Halula data or the spike events proposed by Ben-Yosef et al. (2009) and Shaar et al. (2011) at the very beginning of the first millennium BC.

The second approach is similar to the method described above but relies on the more complex cubic B-splines time parameterization and uses an iterative scheme to identify and then to weight the data that are considered as outliers (Fig. 8b; modified 440 from Thébault and Gallet, 2010). The algorithm first proposes a set of possible spline 441 knots irregularly spaced. The spacing is designed to take full advantage of the varying 442 time resolution between epochs that arises from the uneven time distribution of the 443 reference archeomagnetic data. For instance, it is found that the maximum achievable 444 time resolution is about 150 years between $7000 \mathrm{BC}$ to about $5000 \mathrm{BC}$ and between $445 \sim 3000 \mathrm{BC}$ and $2000 \mathrm{AD}$, while searching for features with time resolution lower than 446800 years makes little sense between $\sim 5000 \mathrm{BC}$ and $\sim 3000 \mathrm{BC}$. Then, the data are as 447 before 1000 times randomly noised within their a priori error bars. For each curve, the 448 algorithm checks whether the maximum likelihood solution belongs to the a priori 95\% 449 error bar of the data and weights accordingly the data that are systematically outside 450 this confidence interval. Fig. 8b displays the final solution with the maximum probability 
451 in black and its 95\% fluctuation envelope in light blue. This envelope contains 95\% of

452 the maximum likelihood curves estimated by the bootstrap for the 1000 iterations, and

453 it highlights the variability between the different curves. This parameter is important for

454 testing the precision of the most probable curve and for identifying the fine time

455 variations that persist after resampling. Formally, however, the statistical significance of

456 a time variation can be assessed only after the computation of the $95 \%$ confidence

457 interval (in red) that is traditionally calculated a posteriori from the misfit function

458 between the data and the ensemble of models. Compared to the first approach, the

459 likelihood solution provided in supplementary Table 3 is generally smoother. This

460 feature is desired for testing whether the apparent fine time variation of the maximum

461 likelihood can be considered as robust. A striking feature emerging from the comparison

462 between Fig. 8a and Fig. $8 \mathrm{~b}$ is that the final solution is independent of the chosen

463 modeling scheme. This is seemingly positive evidence that the observed magnetic field

464 intensity variations are well constrained (within the given time resolution) by the

465 available data in the chosen geographical area.

466 We then sought to constrain the variations in global geomagnetic dipole field 467 moment over the past 9 millennia. For this, we averaged the archeointensity data 468 available in the Middle East over sliding windows of 500 years, roughly assuming that 469 this rather long duration may suffice to average out most of the non-dipole 470 contributions (e.g. Hulot and Le Mouël, 1994; Genevey et al., 2008; Knudsen et al., 2008).

471 On the other hand, this averaging smoothes out the more rapid variations in dipole 472 moment over centennial time scales (Genevey et al., 2009; 2013). The curve constructed 473 using the same technique as in Fig. 8a is shown in Fig. 9a, together with the VADM 474 computed by Knudsen et al. (2008) using the global GEOMAGIA50 database (Korhonen 475 et al., 2008) and applying both temporal and geographical averaging to eliminate the 476 non-dipole components. As a general comment, the two curves exhibit the same dipole 477 behavior during the past three millennia (although the magnitude and the amplitude of 478 the variations are not strictly the same), characterized by two periods of stronger dipole 479 moment during the first millennium BC and during the second half of the first 480 millennium AD (see also Genevey et al., 2008; Hong et al., 2013). In contrast, these 481 curves are significantly different during the third millennium BC, with a smooth VADM 482 evolution in the case of the Knudsen et al. (2008) curve but with a distinct dipole 483 maximum in our Middle East curve. For older periods, there is again a good consistency 
484 between the two curves, but we note the large error bars of Knudsen et al.'s (2008) 485 curve for the 7 th-6th millennium segment. Thus the question remains as to the 486 significance of the dipole maximum observed in the Middle East during the third 487 millennium $\mathrm{BC}$, which is well constrained by a significant number of data. Owing to the 488 rather good agreement between the two curves, especially during the past three 489 millennia, the VADM maximum we observe during the third millennium BC might well 490 be a global (dipole) geomagnetic feature that requires further confirmation. If true, it 491 would indicate that the dipole evolution varied more erratically than previously thought, 492 with an oscillatory behavior at least between $~ 3000 \mathrm{BC}$ and $2000 \mathrm{AD}$ of typical time 493 scale of about 1700 years (see also Burakov et al., 1998).

Fig. 9b compares our VADM variation curve with dipole moments derived from 495 global geomagnetic field modeling that was recently constructed using only 496 archeomagnetic and volcanic data (Pavón-Carrasco et al., 2014, in blue) and another that 497 also incorporated paleomagnetic data from sediments (Nilsson et al., 2014 in orange and 498 green; note that this latter reconstruction supersedes the previous field reconstruction 499 of Korte et al., 2011). The field models that partly rely on sediment data naturally show 500 time variations smoother than that of the models constructed using only the 501 archeomagnetic and volcanic data. Hence, the dipole moments derived by Nilsson et al. 502 (2014) during the 7th millennium BC are lower than the ones proposed by Pavón503 Carrasco et al. (2014) and lower than the averaged VADM we estimated from the Middle 504 East. However, at the beginning of the first millennium BC, the VADM values from the 505 Middle East are much higher than the dipole moments from either models. Neither of 506 two reconstructions shows the distinct dipole maxima previously observed during the 507 past three millennia (Fig. 9a; Genevey et al., 2008; Knudsen et al., 2008), in particular the 508 one dated to the first millennium AD. This clearly poses the question of the consistency 509 between the VADM estimates and the time-varying dipole moment reconstructions. 510 Nevertheless, it could be argued that the field modeling of Pavón-Carrasco et al. (2014) 511 gives some support to the occurrence of a dipole moment maximum during the third 512 millennium BC (Fig. 9b). Such an agreement still needs to be confirmed because the 513 proposed field reconstruction shows numerous centennial-scale fluctuations with 514 similar amplitudes over the entire sequence, a feature whose geomagnetic origin is 515 questionable. 


\section{ACCEPTED MANUSCRIPT}

As a concluding remark, we point out that the different time-varying archeomagnetic field reconstructions encompassing the 7 th-5th millennium time interval all suffer from the erroneous dating affecting the Yarim Tepe II and Tell Sotto data. Together with the corrected Yarim Tepe II and Tell Sotto ages, the new archeointensity data obtained in the present study dated to between $7000 \mathrm{BC}$ and 5000 $\mathrm{BC}$ will help improve the reliability of the next generation of geomagnetic field models spanning the Late Neolithic period. Besides implications for geomagnetism, this improvement may be of particular interest in providing chronological time constraints for archeological purposes, during a fascinating period (e.g. Berger and Guilaine, 2009) that was marked by the beginning of the Neolithic expansion from the Middle East toward Western Europe.

\section{Acknowledgements}

We thank Michel Al Maqdissi (DGAM, Damascus), who made possible this archeomagnetic study. We are also grateful to Stuart Gilder and 2 anonymous reviewers for helpful comments on the manuscript. Y.G. and I.N. were partly financed by grant of the Russian Ministry of Science and Education N 14.Z50.31.0017. IPGP contribution no. $\mathrm{Xxx}$

\section{References}

Akkermans, P.M.M.G., Schwartz, G.M., 2003. The archaeology of Syria. From complex hunter-gatherers to early urban societies (ca. 16,000-300 BC). Cambridge World Archaeology, Cambridge University Press, New York, 467 pp.

Bader, N., 1989. Earliest Cultivators in Northern Mesopotamia. The Investigations of Soviet Archaeological Expedition in Iraq at Settlements Tell Magzaliya, Tell Sotto, Kül Tepe. Moscow, Nauka.

Bader, N., Le Mière, M., 2013. From pre-Pottery Neolithic to Pottery Neolithic in the Sinjar, in Interpreting the Late Neolithic of Upper Mesopotamia. Publications on Archaeology of the Leiden Museum of Archaeology (PALMA), Brepols pub. (Turnhout, Belgium), 513-520. 
546 Bernbeck, J., Nieuwenhuyse, O.P., 2013. Established paradigms, current disputes and emerging themes: the state of research on the Late Neolithic in Upper Mesopotamia, in Interpreting the Late Neolithic of Upper Mesopotamia. Publications on Archaeology of the Leiden Museum of Archaeology (PALMA), Brepols pub. (Turnhout, Belgium), 17-37.

Ben-Yosef, E., Ron, H., Tauxe, L., Agnon, A., Genevery, A., Levy, T.E., Avner, U., Najjar, M., 2008. Application of copper slag in geomagnetic archaeointensity research. J. Geophys. Res. 113, B08101. doi:10.1029/2007JB005235.

Ben-Yosef, E., Tauxe, L., Levy, T.E., Shaar, R., Ron, H., Najjar, M., 2009. Geomagnetic intensity spike recorded in high resolution slag deposit in southern Jordan. Earth Planet. Sci. Lett. 287, 529-539.

Berger, J.-F., Guilaine, J., 2009. The 8200 calBP abrupt environmental change and the Neolithic transition: A Mediterranean perspective. Quaternary Int. 200, 31-49.

Burakov, K.S., Galyagin, D.K., Nachasova, I.E., Reshetnyak, M. Yu., Sokolov, D.D., Frick, P.G., 1998. Wavelet analysis of geomagnetic field intensity for the past 4000 years. Izvestiya Phys. of Solid Earth 34 (9), 773-778.

Campbell, S., 2007. Rethinking Halaf chronology. Paléorient 33, 103-136.

Campbell, S., Fletcher, A., 2010. Questioning the Halaf-Ubaid Transition. In: Beyond the Ubaid: Transformation and integration in the late prehistoric societies of the Middle East, R.A. Carter and G. Philip eds., SAOC: Studies in Ancient Oriental Civilization 63, The Oriental Institute of the University of Chicago, 69-83.

Coe, R. S., 1967. Paleo-Intensities of the Earth's magnetic field determined from Tertiary and Quaternary Rocks. J. Geophys. Res. 72, 3247-3262.

Cruells, W., Nieuwenhuyse, 0., 2004. The proto-Halaf period in Syria. New sites, new data. Paléorient 30, 47-68.

Day, R., Fuller, M., Schmidt, V., 1977. Hysteresis properties of titanomagnetites: grain size and composition dependence. Phys. Earth Planet. Inter. 13, 260-267.

De Marco, E., Spatharas, V., Gomez-Paccard, M., Chauvin, A., Kondopoulou, D., 2008. New archeointensity resulst from archeological sites and variations of the geomagnetic field intensity for the last 7 millennia in Greece. Phys. Chem. Earth 33, 578-595. 
576 Dunlop, D.J., 2002a. Theory and application of the Day plot (Mrs/Ms versus Hcr/Hc) 1. Theoretical curves and tests using titanomagnetite data. J. Geophys. Res. 107, 2056, 10.1029/2001JB000486.

Dunlop, D.J., 2002b. Theory and application of the Day plot (Mrs/Ms versus Hcr/Hc) 2 . Application to data for rocks, sediments, and soils. J. Geophys. Res. 107, 2057, 10.1029/2001JB000487.

Ertepinar, P., Langereis, C.G., Biggin, A.J., Frangipane, M., Matney, T., Ökse, T., Engin, A., 2012. Archaeomagnetic study of five mounds from Upper Mesopotamia between 2500 and 700 BC: further evidence for an extremely strong geomagnetic field ca. 3000 years ago. Earth Planet. Sci. Lett. 357-358, 84-98.

Gallet, Y., Le Goff, M., 2006. High-temperature archeointensity measurements from Mesopotamia. Earth Planet. Sci. Lett. 241, 159-173.

Gallet, Y., Genevey, A., Le Goff, M., Fluteau, F., Eshraghi, S.A., 2006. Possible impact of the Earth's magnetic field on the history of ancient civilizations. Earth Planet. Sci. Lett. 246, 17-26.

Gallet, Y., Le Goff, M., Genevey, A., Margueron, J., Matthiae, P., 2008. Geomagnetic field intensity behavior in the Middle East between 3000 BC and 1500 BC. Geophys. Res. Lett. 35, L02307. doi: 10.1029/2007GL031991.

Gallet, Y., Genevey, A., Le Goff, M., Warmé, N., Gran-Aymerich, J., Lefèvre A., 2009a. On the use of archeology in geomagnetism, and vice-versa: Recent developments in archeomagnetism. C. R. Physique 10, 630-648.

Gallet, Y., Hulot, G., Chulliat, A., Genevey, A., 2009b. Geomagnetic field hemispheric asymmetry and archeomagnetic jerks. Earth Planet. Sci. Lett. 284, 179-186.

Gallet, Y., D’Andrea, M., Genevey, A., Pinnock, F., Le Goff, M., Matthiae, P., 2014. Archaeomagnetism at Ebla (Tell Mardikh, Syria). New data on geomagnetic field intensity variations in the Near East during the Bronze Age. J. Archaeol. Sci. 42, 295-304.

Gallet, Y., Butterlin, P., 2014. Archaeological and geomagnetic implications of new archaeomagnetic intensity data from the Early Bronze high terrace "Massif Rouge" 


\section{ACCEPTED MANUSCRIPT}

605

606

607

608

609

610

611

612

613

614

615

616

617

618

619

620

621

622

623

624

625

626

627

628

629

630

631

632

633

634

at Mari (Tell Hariri, Syria). Archaeometry online 5 June 2014, doi: 10.111/arcm.12112.

Gallet, Y., Al Maqdissi, M., 2010. Archéomagnétisme à Mishirfeh-Qatna: Nouvelles données sur l'évolution de l'intensité du champ magnétique terrestre au MoyenOrient durant les derniers millénaires. Akkadica 131, 29-46.

Genevey, A., Gallet, Y., 2002. Intensity of the geomagnetic field in Western Europe over the past 2000 years: New data from ancient French pottery. J. Geophys. Res. 107, B11.

Genevey, A., Gallet, Y., Margueron, J., 2003. Eight thousand years of geomagnetic field intensity variations in the eastern Mediterranean. J. Geophys. Res 108, 2228. doi:10.1029/2001JB001612.

Genevey, A., Gallet, Y., Constable, C., Korte, M., Hulot, G., 2008. ArcheoInt: An upgraded compilation of geomagnetic field intensity data for the past ten millennia and its application to the recovery of the past dipole moment. Geochem. Geophys. Geosys. 9(4), Q04038. doi: 10.1029/2007GC001881.

Genevey, A., Gallet, Y., Rosen, J., Le Goff, M., 2009. Evidence for rapid geomagnetic field intensity variations in Western Europe over the past 800 years from new archeointensity French data. Earth Planet. Sci. Lett. 284, 132-143. doi:10.1016/j.epsl.2009.04.024.

Genevey, A., Gallet, Y., Thébault, E., Jesset, S., Le Goff, M., 2013. Geomagnetic field intensity variations in Western Europe over the past 1100 years. Geochem. Geophys. Geosyst. 14/8, 2858-2872

Gómez, A., 2011. Caracterización del producto cerámico en las comunidades neolíticas de mediados del VI milenio cal BC: el valle del Éufrates y el valle del Khabur en el Halaf Final. PhD Thesis, Universitat Autónoma de Barcelona, Spain.

Hartmann, G., Genevey, A., Gallet, Y., Trindade, R., Etchevarne, C., Le Goff, M., Afonso, M., 2010. Archeointensity in Northeast Brazil over the past five centuries. Earth Planet. Sci. Lett. 296, 340-352.

Hartmann, G., Genevey, A., Gallet, Y., Trindade, R., Le Goff, M., Najjar, R., Etchevarne, C., Afonso, M., 2011. New historical archeointensity data from Brazil : Evidence for a 
635

large regional non-dipole field contribution over the past few centuries. Earth Planet. Sci. Lett. 306, 66-76.

Hong, H., Yu, Y., Lee, C.H., Kim, R.H., Park, J., Doh, S.-J., Kim, W., Sung, H., 2013. Globally strong geomagnetic field intensity circa 3000 years ago. Earth Planet. Sci. Lett. 383, 142-152.

Hours, F., Aurenche, O, Cauvin, J., Cauvin, M.C., Copeland, L., Sanlaville, P., 1994. Atlas des sites du Proche-Orient (14000-5700 BP). Travaux de la Maison de l'Orient Méditerranéen 24, Lyon.

Hulot, G., Le Mouël, J.-L., 1994. A statistical approach to the Earth' s main magnetic field. Phys. Earth Planet. Inter. 82, 167-183.

Knudsen, M. Riisager, P., Donadini, F., Snowball, I., Muscheler, R., Korhonen, K., Pesonen, L., 2008. Variations in geomagnetic dipole moment during the Holocene and the past 50 kyr. Earth Planet. Sci. Lett. 272, 319-329.

Korhonen, K., Donadini, F., Riisager, P., Pesonen, L.J., 2008. GEOMAGIA50: An archeointensity database with PHP and MySQL. Geochem. Geophys. Geosyst. 9, Q04029.

Korte, M., Donadini, F., Constable, C., 2009. Geomagnetic field for 0-3 ka: 2. A new series of time-varying global models. Geochem. Geophys. Geosyst. 10, Q06008.

Korte, M., Constable, C., Donadini, F., Holme, R., 2011. Reconstructing the Holocene geomagnetic field. Earth Planet. Sci. Lett. 312, 497-505.

Kostadinova-Avramova, M., Kovacheva, M., Boyadzhiev, Y., 2014. Contribution of stratigraphic constraints of Bulgarian prehistoric multilevel tells and a comparison with archaeomagnetic observations. J. Archaeol. Sci. 43, 227-238.

Kovacheva, M., Kostadinova-Avramova, M., Jordanova, N., Lanos, P., Boyadziev, Y., 2014. Extended and revised archaeomagnetic database and secular variation curves from Bulgaria for the last eight millennia. Phys. Earth Planet. Inter. In press, doi: 10.1016/j.pepi.2014.07.002.

Le Goff, M., Gallet, Y., 2004. A new three-axis vibrating sample magnetometer for continuous high-temperature magnetization measurements: applications to paleoand archeo-intensity determinations. Earth Planet. Sci. Lett. 229, 31-43. 


\section{ACCEPTED MANUSCRIPT}

665 Le Mière, M., Picon, M., 1998. Les débuts de la céramique du Proche-Orient. Paléorient 24/2, 27-48.

667

668

669

670

671

672

673

674

675

676

677

678

679

680

681

682

683

684

685

686

687

688

689

690

691

692

693

694

Licht, A., Hulot, G., Gallet, Y., Thébault, E., 2013. Ensembles of low degree archeomagnetic field models for the past three millennia. Phys. Earth Planet. Inter. 224, 38-67.

Livermore, P.W., Fournier, A., Gallet, Y., 2014. Core-flow constraints on extreme archeomagnetic intensity changes, Earth Planet. Sci. Lett. 387, 145-156

Masetti-Rouault, M.-G., 2005. Mission archéologique française à Tell Masaïkh, projet Terqa et sa région. Rapport préliminaire de la mission 2005 à Tell Masaïkh", p. 112.

Masetti-Rouault, M.-G., 2006. Rapporto preliminare sui lavori della missione nel sito di Tell Masaïkh nel 2005 (MK10). In : Rouault O. et Mora C., Progetto Terqa e la sua regione (Siria). Rapporto preliminare 2005, Athenaeum fasc. 2, p. 749-756.

Masetti-Rouault, M.-G., . Rural Economy and Steppe Management in an Assyrian Colony in the West. A view from Tell Masaïkh Lower Middle Euphrates, Syria. In: H. Kühne ed. Dur-Katlimmu 2008 and Beyond, Studia Chaburensia, vol. 1, Harrassowitz Verlag, 130-149.

McIntosh, G., Kovacheva, M., Catanzariti, G., Osete, M.L., Casas, L., 2007. Widespread occurrence of a novel high coercivity, thermally stable, low unblocking temperature magnetic phase in heated archeological material. Geophys. Res. Lett. 34, L21302.

McIntosh, G., Kovacheva, M., Catanzariti, G., Donadini, F., Lopez, M.L.O., 2011. High coercivity remanence in baked clay materials used in archeomagnetism. Geochem. Geophys. Geosyst. 12, Q02003, doi:10.1029/2010GC003310.

Molist, M., 1996 (ed.). Tell Halula (Siria). Un yacimiento neolítico del valle medio del Éufrates. Campañas de 1991 y 1992. Ediciones del Ministerio de Educación y Ciencia, Madrid Spain, 223 p.

Molist, M. ,1998. Espace collectif et domestique dans le néolithique des IXème et VIIIème millénaires B.P. au nord de la Syrie: apports du site de Tell Halula (Vallée de l'Euphrate), in Espace Naturel, Espace Habité en Syrie du Nord. (10e-2e millénaires av. J. C.). M. Fortin and O. Aurenche eds., 115-130, Québec-Lyon, BCSMS-TMO. 


\section{ACCEPTED MANUSCRIPT}

695

696

697

698

699

700

701

702

703

704

705

706

707

708

709

710

711

712

713

714

715

716

717

718

719

720

721

722

723

724

Molist, M., Faura, J.M., 1999. Tell Halula: Un village des premiers agriculteurs-éleveurs dans la Vallée de l'Euphrate, in Archaeology of the Upper Syrian Euphrates. The Tishrin Dam Area, Del Olmo, G. and Montero J. L. (eds.), Proceedings of the International Symposium held at Barcelona, January 28-30 1998, Ed. Ausa, Sabadell: 27-40.

Molist, M., 2001. Halula, village néolithique en Syrie du Nord, in Communautés villageoises du Proche-Orient à l'Atlantique (8000-2000 av. J.-C.), Guilaine J. (ed), 115-130, Paris, Editions Errance.

Molist, M., Anfruns, J., Borrell, F., Clop, X., Cruells, W., Gómez, A., Guerrero, E., Tornero, C., Sana, M., 2007. Tell Halula (vallée de l’Euphrate, Syrie): nouvelles données sur les occupations Néolithiques. Notices préliminaires sur les travaux 2002-2004. In Les résultats du programme de formation à la sauvegarde du patrimoine culturel de Syrie, Abdul Massih J. (ed.), 21-52, Damas: Ministère de la culture, Direction générale des antiquités et des musées (Documents d’archéologie syrienne 11).

Molist, M., Anfruns, J., Bofill, M., Borrell, F., Buxó, R., Clop, X., Cruells, W., Faura, J.M., Ferrer, A., Gómez, A., Guerrero, E., Saña, M., Tornero, C. \& Vicente, O., 2013. Tell Halula (Euphrates Valley, Syria): New approach to VII and VI millennia cal. B.C. in Northern Levant framework, in Interpreting the Late Neolithic of Upper Mesopotamia. Publications on Archaeology of the Leiden Museum of Archaeology (PALMA), Brepols pub. (Turnhout, Belgium), 443-455.

Nachasova, I., Burakov, K., 1995. Archaeointensity of the geomagnetic field in the fifth millennium B.C. in northern Mesopotamia. Geomagn. Aeron. 35, 398-402.

Nachasova, I., Burakov, K., 1998. Geomagnetic variations in the VI-V millennia B.C. Geomagn. Aeron. 38, 502-505.

Nieuwenhuyse, O., Akkermans, P., van der Plicht, J., 2010. Not so coarse, nor always plain -the earliest pottery of Syria. Antiquity 84, 71-85.

Nieuwenhuyse, O.P., Bernbeck, R., Akkermans, P.M.M.G., Rogasch, J., 2013. Interpreting the Late Neolithic of Upper Mesopotamia, Publications on Archaeology of the Leiden Museum of Archaeology (PALMA), Brepols pub. (Turnhout, Belgium), 520 pp. 
Nilsson, A., Snowball, I., Muscheler, R., Uvo, C.B., 2010. Holocene geocentric dipole tilt model constrained by sedimentary paleomagnetic data. Geochem. Geophys. Geosyst. 11, Q08018.

Nilsson, A., Holme, R., Korte, M., Suttie, N., Hill, M., 2014. Reconstructing Holocene geomagnetic field variation: New methods, models and implications, Geophys. J. Int. in press.

Nishiaki, Y., Le Mière, M., 2005. The oldest pottery Neolithic of Upper Mesopotamia: New evidence from Tell Seker al-Aheimar, the Khabur, northeast Syria. Paléorient 31, $55-68$

Pavón-Carrasco, F.J., Osete, M.L., Torta, J.M., De Santis, A., 2014. A geomagnetic field model for the Holocene based on archaeomagnetic and lava flow data. Earth Planet. Sci. Lett. 388, 98-109.

Robert, B., Blanc, C., Chapoulie, R., Masetti-Rouault, M.-G., 2008. Characterizing the HalafUbaid Transitional Period by Studying Ceramic from Tell Masa ${ }^{2}$, Syria. Archaeological Data and Archaeometry Investigations. In : H. Kühne, R.M. Czichon, F.J. Kreppner (eds.), Social and Cultural Transformation : The Archaeology of the Transitional Periods and Dark Ages Excavation Reports (Vol. 2), Proceedings of the 4th International Congress of Archaeology of the Near East, 29 March - 3 April April 2004, Freie Universität Berlin, Harrassowitz Verlag, Wiesbaden, 225-234.

Robert, B., 2009. Production céramique et représentations animales à l'époque de Halaf. Res Antiquae 6, 271-292.

Robert, B., 2010. Développement et disparition de la production céramique halafienne: implications techniques et sociales à partir d'études de cas. $\mathrm{PhD}$ thesis Université Lumière Lyon 2, pp. 899.

Shaar, R., Ben-Yosef, E., Ron, H., Tauxe, L., Agnon, A., Kessel, R., 2011. Geomagnetic field intensity: How high can it get? How fast can it change? Constraints from Iron-Age copper-slag. Earth Planet. Sci. Lett. 301, 297-306.

Shaar, R., Tauxe, L., Ben-Yosef, E., Kassianidou, V., Lorentzen, B., Feinberg, J.M., Levy, T.E., 2014. Decadal-scale variations in geomagnetic field intensity from ancient Cypriot slag mounds. Geochem. Geophys. Geosyst. In press. 


\section{ACCEPTED MANUSCRIPT}

755 Tema, E., Kondopoulou, D., 2011. Secular variation of the Earth's magnetic field in the

756 Balkan region during the last eight millennia based on archaeomagnetic data.

757 Geophys. J. Int. 186(2), 603-614.

758 Thébault, E., Gallet, Y., 2010. A bootstrap algorithm for deriving the archeomagnetic field 759 intensity variation curve in the Middle East over the past 4 millennia BC. Geophys. $760 \quad$ Res. Lett. 37, L22303. Doi:10.1029/2010GL044788.

761 Thellier, E., Thellier, 0., 1959. Sur l'intensité du champ magnétique tesrrestre dans le 762 passé historique et géologique. Ann. Géophys. 15, 285-376

763 Tsuneki, A., Miyake, Y., 1996. The earliest pottery sequence of the Levant: New data from 764 765

Usoskin, I.G., Hulot, G., Gallet, Y., Roth, R., Licht, A., Joos, F., Kovaltsov, G.A., Thébault, E., 766 Khokhlov, A., 2014. Evidence for distinct modes of solar activity. Astronomy \& Astrophysics 562, L10.

768

Valet J.-P., Herrero-Bervera, E. Le Mouël, J.-L., Plénier, G., 2008. Secular variation of the 769 geomagnetic dipole during the past 2000 years. Geochem. Geophys. Geosyst. 9., Q01008.

771

772

773

774

775

776

Van der Plicht, J., Akkermans, P.M., Nieuwenhuyse, O.P., Kaneda, A., Russell, A.L., 2011. Tell Sabi Abyad, Syria: radiocarbon chronology, cultural change, and the $8.2 \mathrm{ka}$ event. Radiocarbon 53(2), 229-243.

Yu, Y., Tauxe, L., Genevey, A., 2004. Toward an optimal geomagnetic field intensity determination technique. Geochem. Geophys. Geosyst. 5(2), Q02H07. 
777 Table caption

778 Table 1. Pottery group-mean intensity values obtained at Tell Halula $\left(\lambda=36^{\circ} 25^{\prime} \mathrm{N}\right.$, $779 \varphi=38^{\circ} 10^{\prime} \mathrm{E}$; pottery groups SY127 to SY132) and Tell Masaïkh $\left(\lambda=34^{\circ} 25^{\prime} \mathrm{N}, \varphi=40^{\circ} 01^{\prime} \mathrm{E}\right.$;

780 pottery groups SY37 and SY38). Information on the different archeological dating, 781 relative chronology and references are provided in the second, third and fourth 782 columns. See text for references on absolute dating (fifth column). * indicates that an 783 approximation was made on the dating (see text). The mean intensity values and their 784 standard deviations are provided in column 6. Column 7 shows the number $\mathrm{Nb}$ of 785 fragments (/n specimens) retained for computing the pottery group-mean intensity 786 values.

Figure captions

789 Fig. 1. (a) Location of the two Syrian archeological sites studied herein (Tell Halula and 790 Tell Masaïkh) and of three other sites discussed in the text (Tell Halaf, Yarim Tepe II and 791 Tell Sotto). (CGoogle Earth. (b) General view of the Tell Halula archeological site. (C) 792 Universitat Autónoma de Barcelona (UAB)/SAPPO.

793 Fig. 2. Examples of pottery sherds discovered at Tell Halula. These fragments are dated 794 to phases I, II and III of the pre-Halaf (photos 1-2, 3-4 and 5-6, respectively), to the 795 proto-Halaf (photos 7-8), and to the Early, Middle and Late Halaf (photos 9, 10-11 and 796 12-13, respectively). (C) Universitat Autónoma de Barcelona (UAB)/SAPPO.

797 Fig. 3. Triaxe intensity data obtained for two specimens from Tell Halula (SY89-08, 798 SY140-06). (a,c) Thermal demagnetization data; (b,d) Triaxe measurement series; (e) 799 Archeointensity results at the specimen level. See text and further explanations in Le 800 Goff and Gallet (2004).

801 Fig. 4. (a) Normalized IRM acquisition curves obtained for one fragment from each time 802 level. (b-c) Two examples of hysteresis loop. (d-g) Four examples of normalized 803 thermomagnetic low-field susceptibility (heating and cooling) curves obtained from 804 fragments collected at Tell Halula. These fragments are dated to the pre-Halaf (d,e), 805 Middle Halaf (f) and to the Late Halaf (g). (h) Hysteresis ratios $\left(M_{R S} / M_{S} v s . H_{C R} / H_{C}\right)$ 806 obtained at Tell Mardikh/Ebla (grey color, Gallet et al., 2014), Tell Masaïkh (blue 
807 triangles) and Tell Halula (see color code on the figure according to the archeological 808 periods of the fragments).

809 Fig. 5. Intensity data obtained from eight different archeomagnetic pottery groups (a-e, 810 Tell Halula; f, Tell Masaïkh). Each colored curve on each of these plots shows the 811 intensity data obtained for one specimen over the temperature range of analysis (for 812 further explanations, see in Le Goff and Gallet, 2004). Altogether, the results from 93 813 specimens are hence reported in this Figure.

814 Fig. 6. Archeomagnetic field intensity variations recovered from the new data obtained 815 at Tell Halula (blue circles) and Tell Masaïkh (blue triangles). All results are converted in 816 Virtual Axial Dipole Moments. The chronological time scale is provided in the text (see 817 also in Table 1).

818 Fig. 7. Comparison between our new archeointensity data (in blue) and previous results 819 obtained (a) from Yarim Tepe II and Tell Sotto (green circles and triangles, respectively), 820 two multi-level archeological sites located in North Iraq (Nachasova and Burakov, 1995, 821 1998) and (b) from Bulgaria (in red; Kovacheva et al., 2014). As discussed in the text, the 822 dating of the Yarim Tepe II and Tell Sotto data was modified from the original papers. 823 The solid vs. open circles indicate the intensity values obtained from several vs. one 824 specimen(s).

825 Fig. 8. Regional averaged geomagnetic field intensity variation curve in the Middle East 826 over the past 9000 years. The data were selected inside a $1000 \mathrm{~km}$-radius circle around 827 the location $\lambda=36^{\circ} 49^{\prime} \mathrm{N}, \varphi=40^{\circ} 02^{\prime} \mathrm{E}$ (archeological site of Tell Halaf). All data were 828 transformed into VADM. Two different approaches were successively considered to 829 compute the curve. (a) We used sliding windows of 200 years shifted every 10 years and 830 the bootstrap technique for taking into account the experimental and age uncertainties 831 on the available intensity data. 1000 curves were hence computed and are shown here 832 the mean (thick black line), the minimum and the maximum VADM values obtained for 833 the different time windows. The Syrian data are also reported (blue dots) together with 834 all other available archeointensity data (grey dots) satisfying minimum selection criteria 835 (Genevey et al., 2008). (b) We used an iteratively reweighted least-squares algorithm, 836 combined with a bootstrap, modified from that of Thébault and Gallet (2010). The 


\section{ACCEPTED MANUSCRIPT}

837 continuous black line shows the maximum of probability, and the light blue lines its $95 \%$

838 fluctuation envelope. The 95\% confidence interval is displayed by the red lines.

839 Fig. 9. Comparison between the geomagnetic field intensity (transformed into VADM)

840 variation curve in the Middle East, with averaging over sliding windows of 500 years

841 (black lines; see text), and previous dipole field moment reconstructions. The

842 comparison is made with (a) the VADM variation curve computed by Knudsen et al.

843 (2008) using temporal and geographic averaging (in red), (b) dipole moment

844 reconstructions derived from different time-varying global geomagnetic field modeling

845 (blue lines, modeling proposed by Pavón-Carrasco et al., 2014; orange and green lines,

846 the pfm9k.1b and pfm9k.1a modeling proposed by Nilsson et al., 2014). 
a)

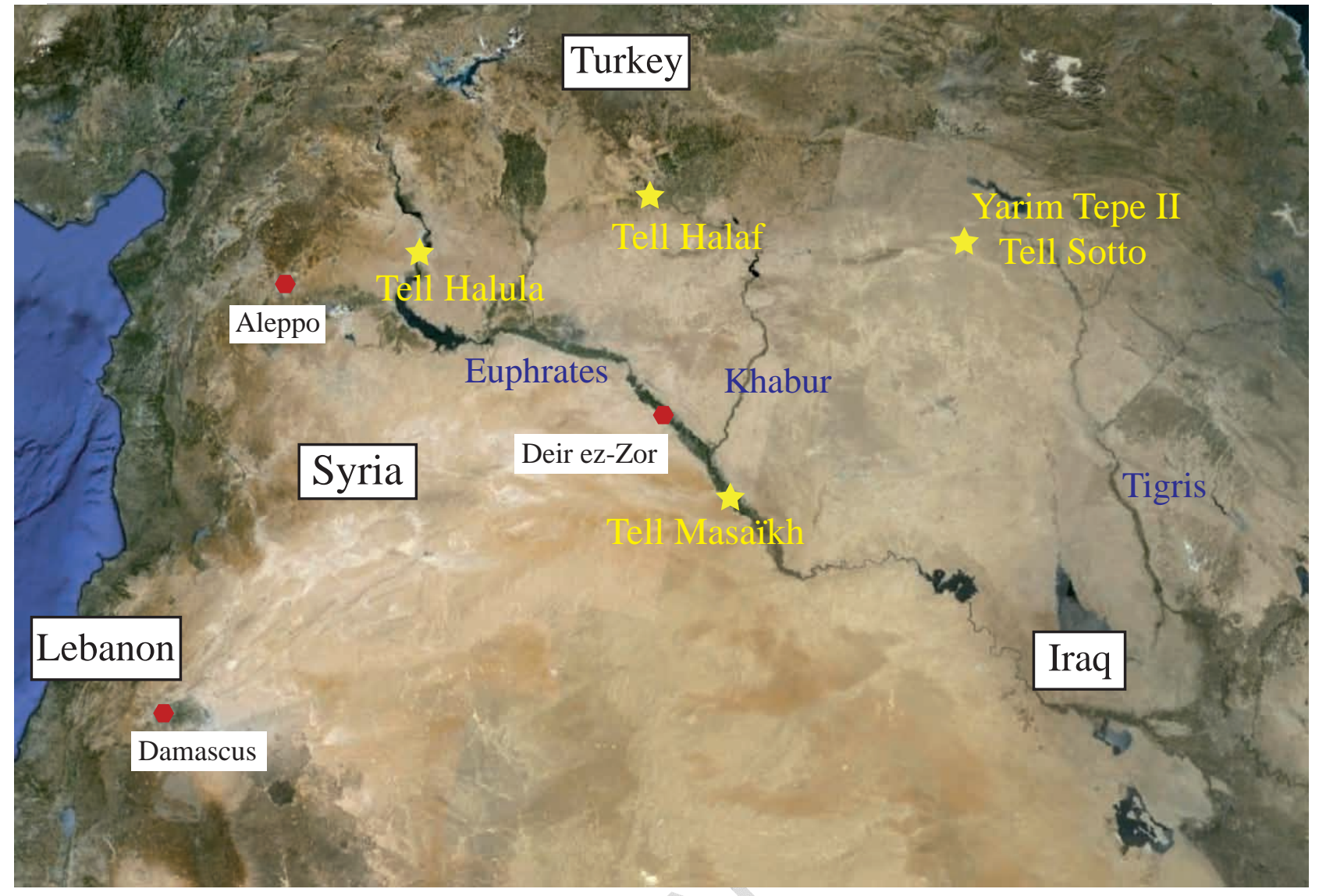

$250 \mathrm{~km}$

b)

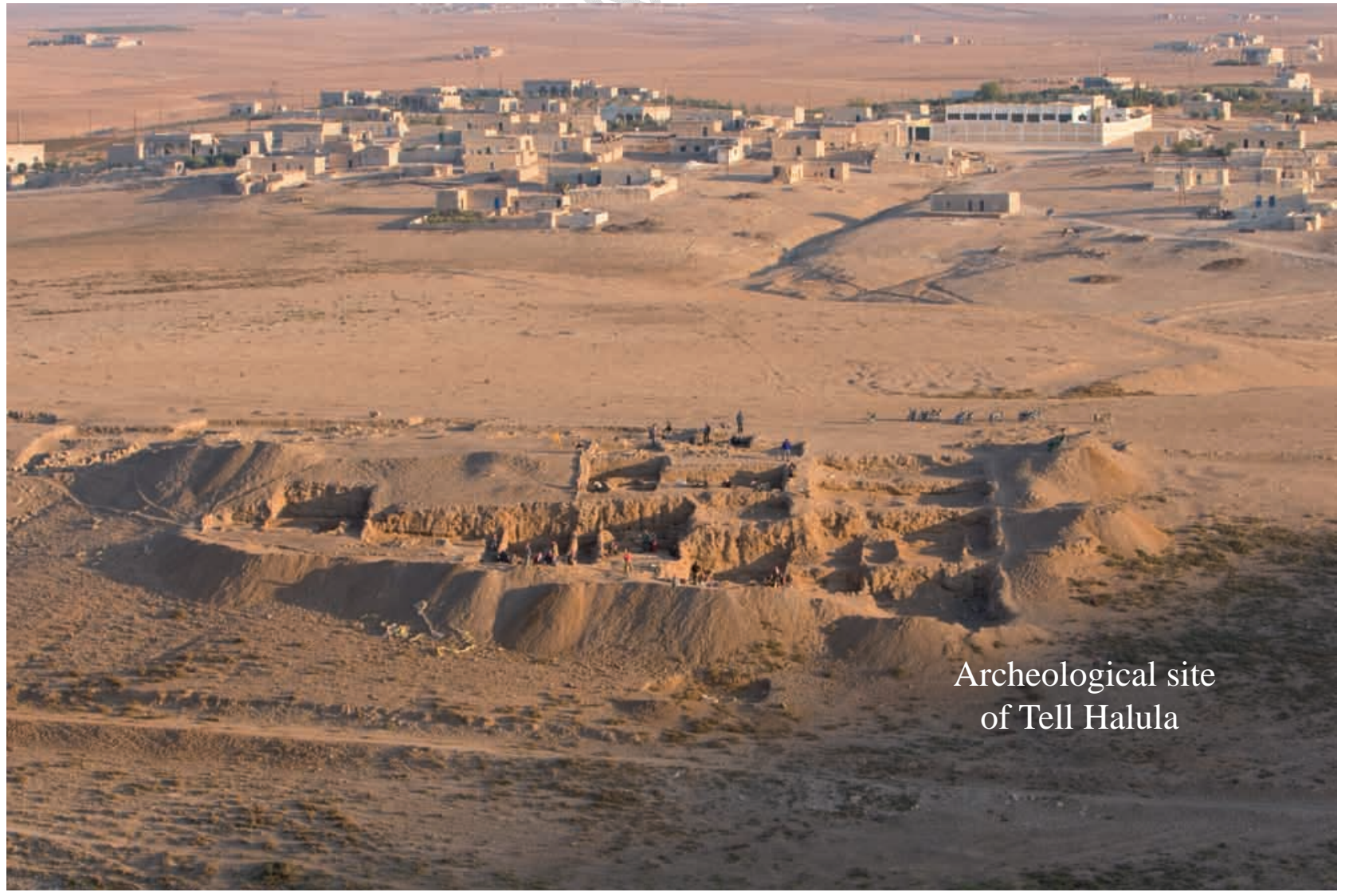

Figure 1 


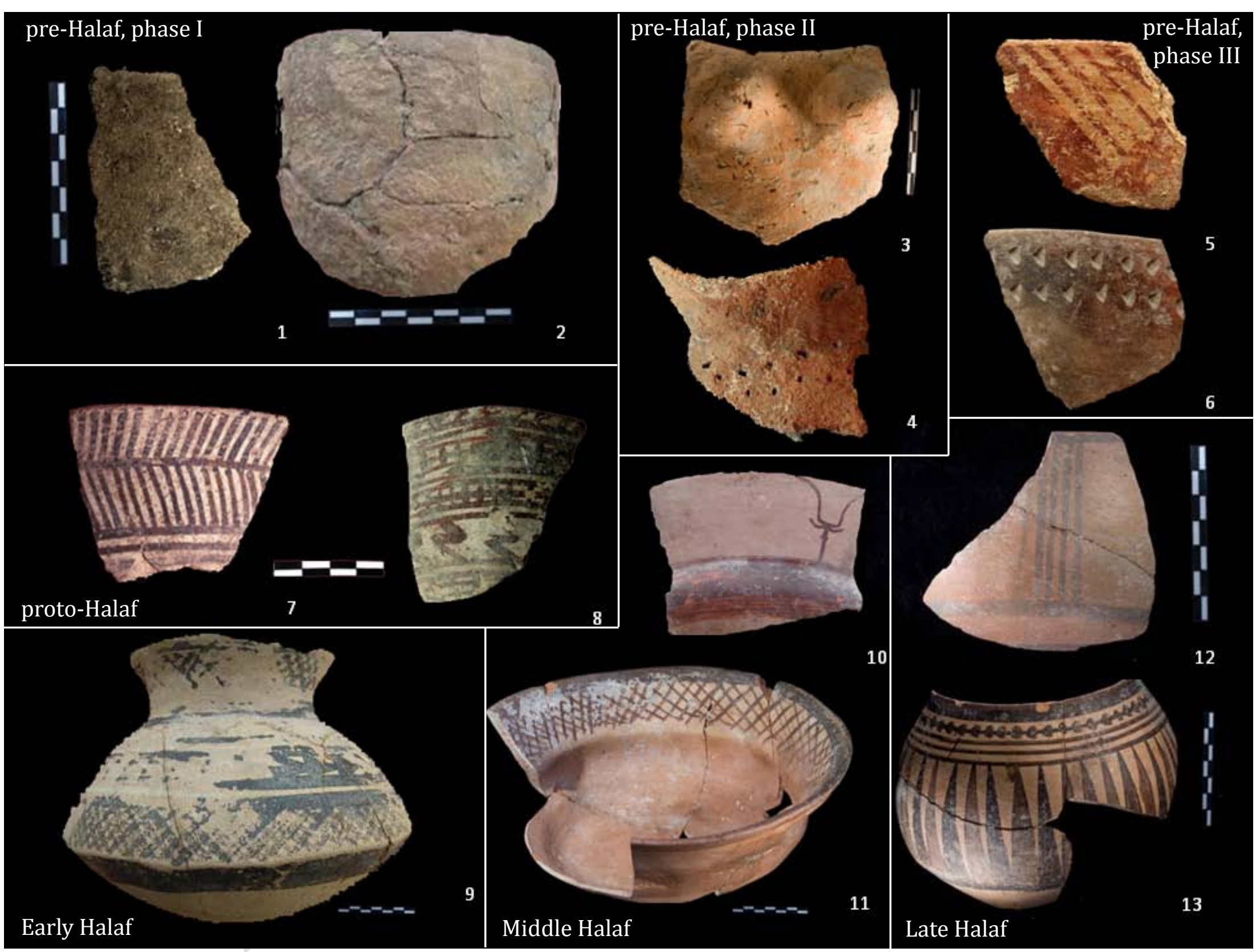

Figure 2 
(a)

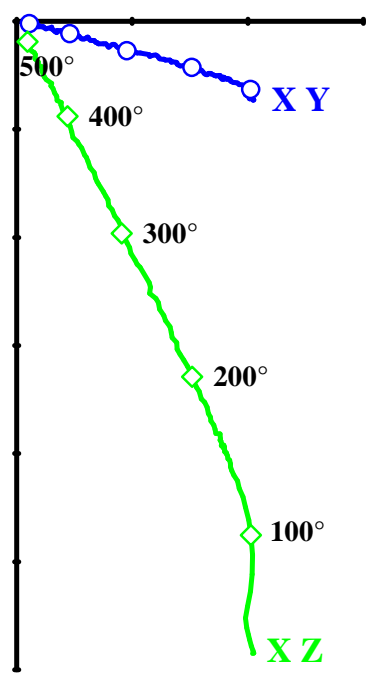

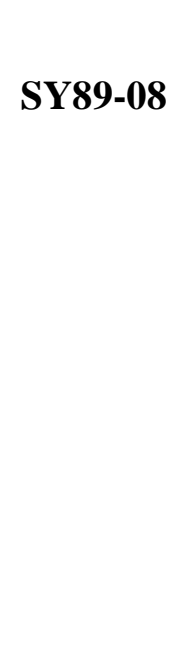
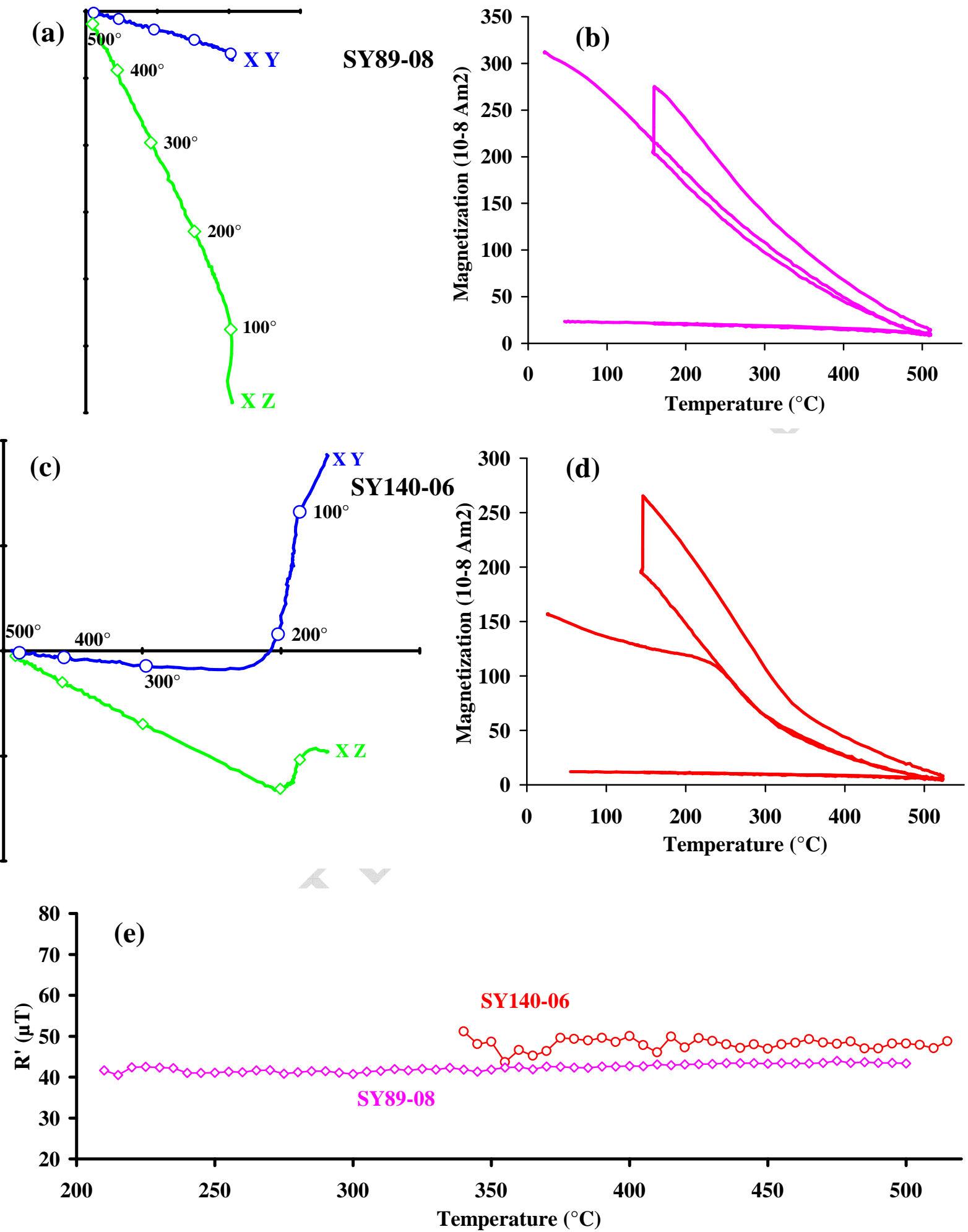

Figure 3 
Figure 4

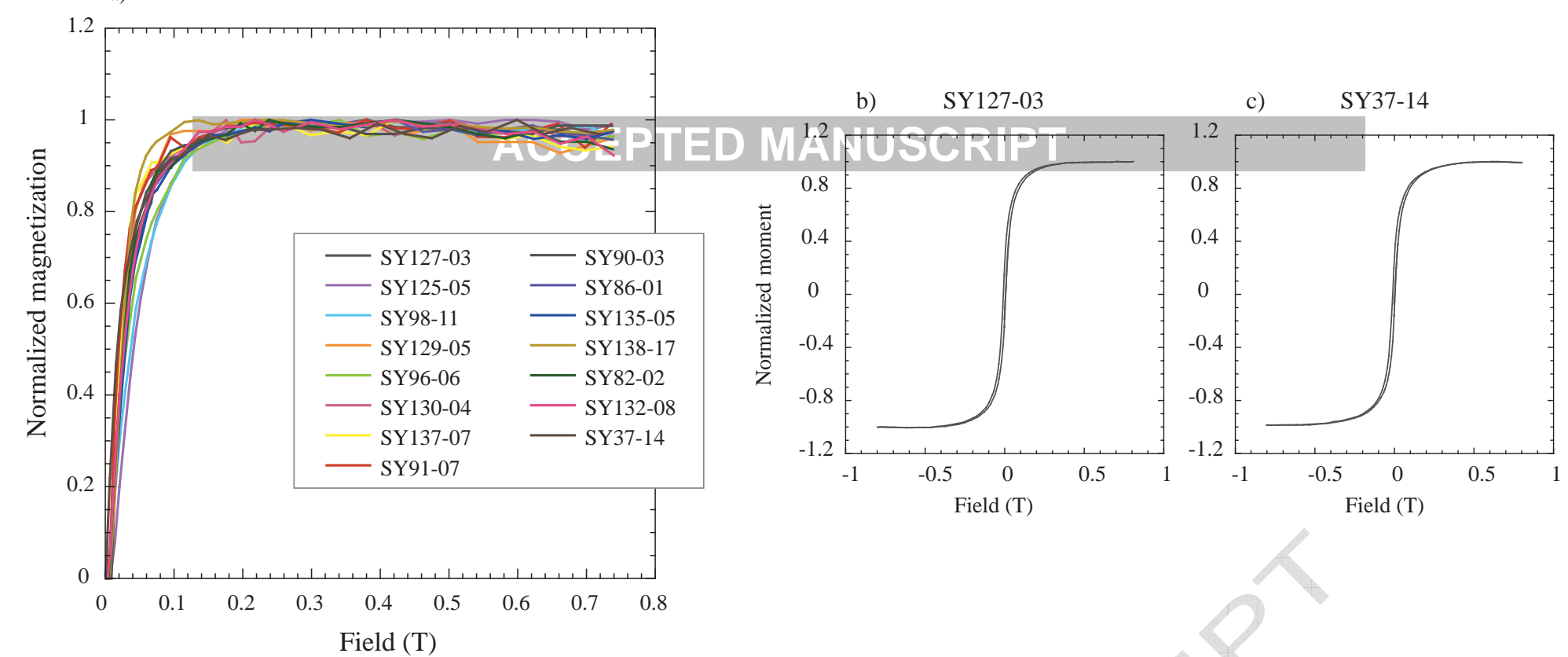

d) SY125-02

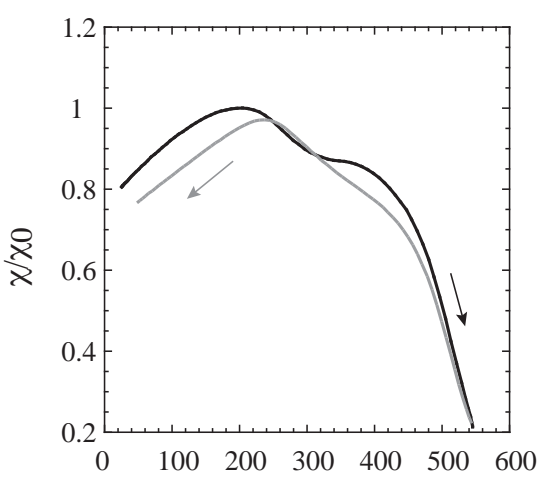

f) SY87-03

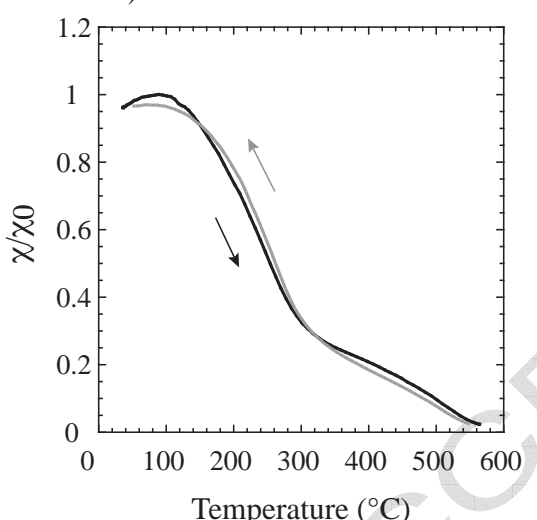

Temperature $\left({ }^{\circ} \mathrm{C}\right)$ e) SY98-02

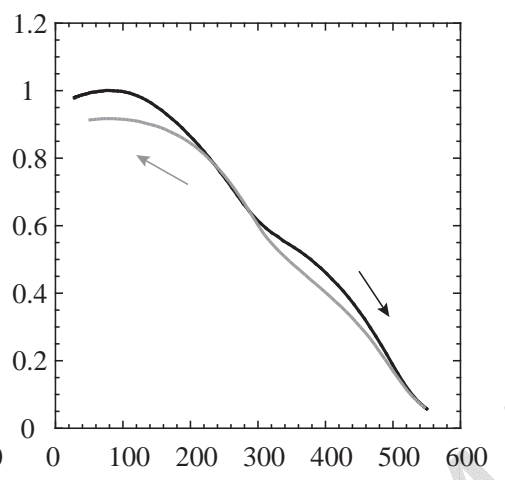

g) SY86-01

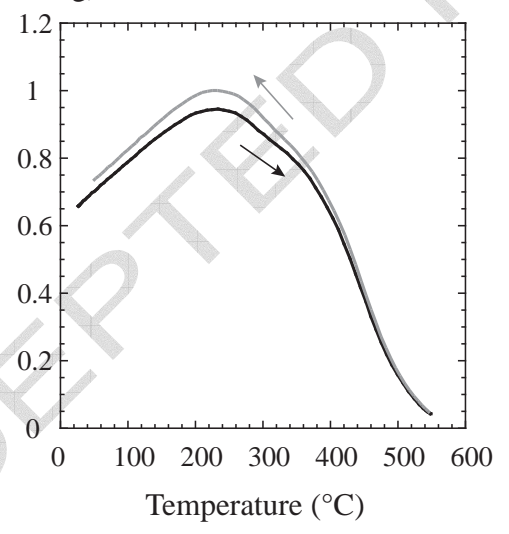

h)

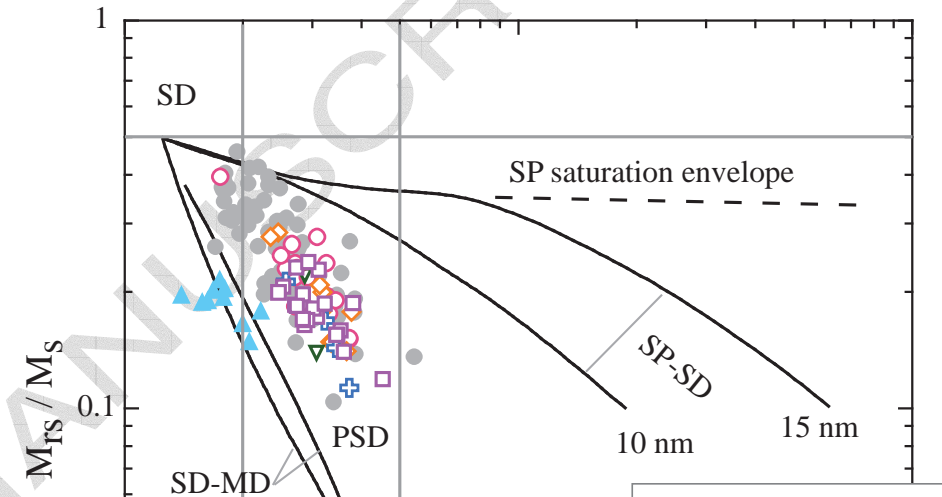

Ebla / Tell Mardikh

A Tell Masaikh Tell Halula

○ Late Halaf

$\diamond$ Middle Halaf

$\nabla$ Early Halaf

↔ Proto-Halaf

ㅁ Pre-Halaf

$$
\mathrm{H}_{\mathrm{cr}} / \mathrm{H}_{\mathrm{c}}
$$




\section{Figure 5}

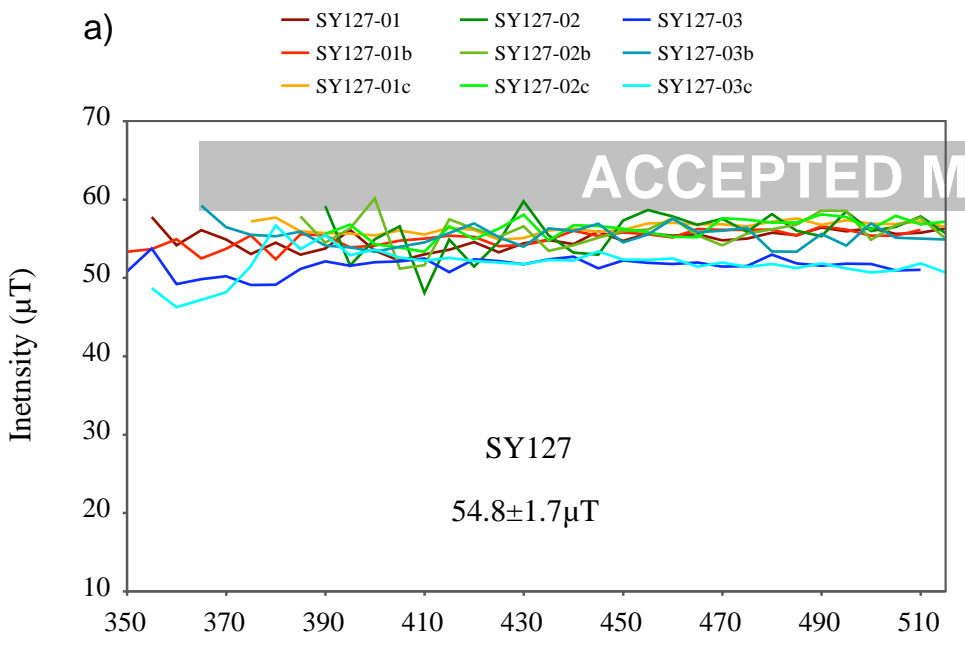

b) $\begin{array}{llll}-\mathrm{SY} 98-02 & -\mathrm{SY} 98-16 & -\mathrm{SY} 128-05 & -\mathrm{s} Y 128-08 \\ -\mathrm{SY} 98-05 & -\mathrm{SY} 98-17 & -\mathrm{SY} 128-06 & -\mathrm{SY} 128-10 \\ -\mathrm{SY} 98-11 & -\mathrm{SY} 98-18 & -\mathrm{SY} 128-07 & -\mathrm{SY} 128-14\end{array}$
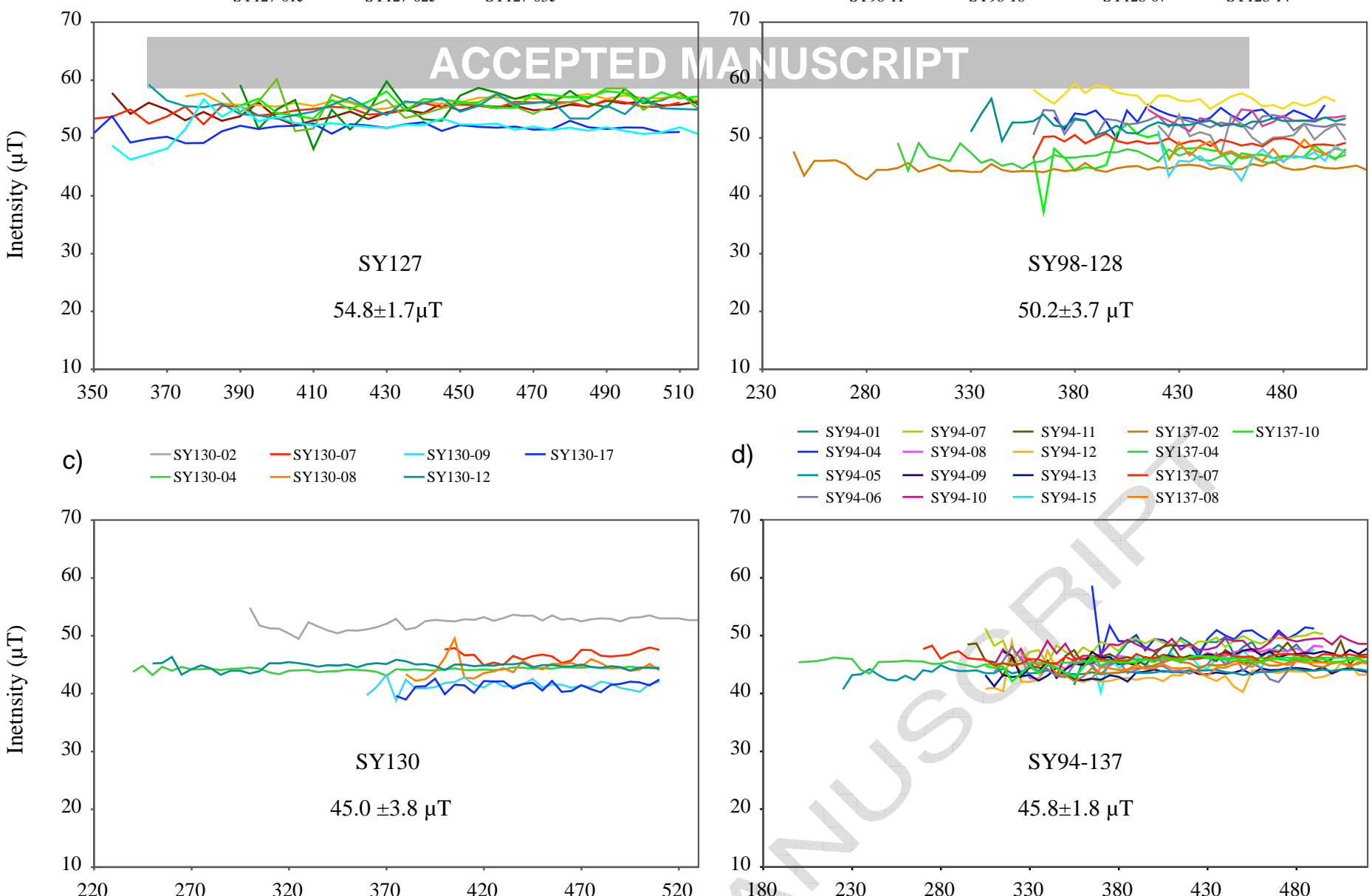
— SY94-01 — SY94-07 — SY94-11 — SY137-02 —SY137-10
d) - SY94-04 — SY94-08 - SY94-12 - SY137-04

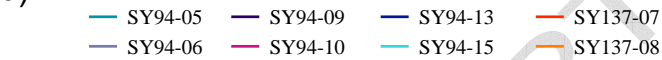

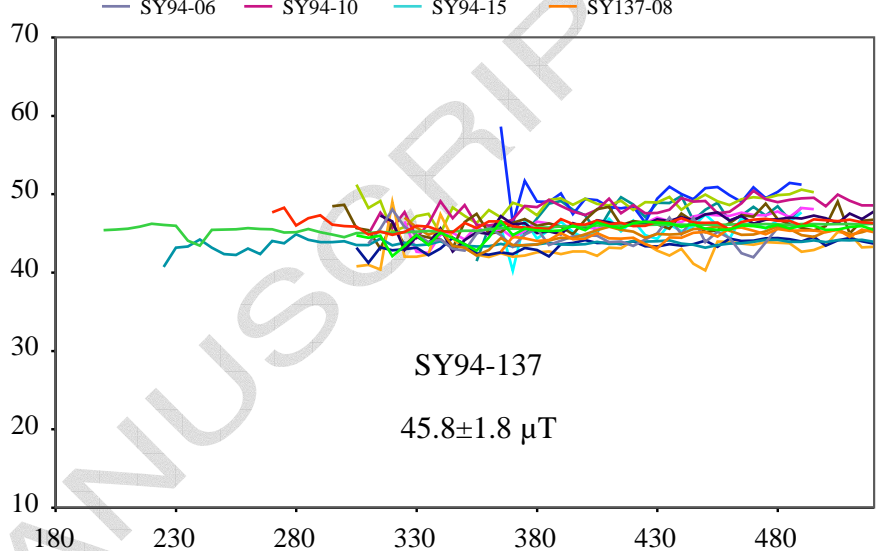

e) $\quad \begin{array}{llll}\text {-SY87-01 } & - \text { SY87-04 } & \text {-SY87-06 } & \text {-SY87-10 } \\ \text { SY87-03 } & - \text { SY87-05 } & \text {-SY87-07 } & \end{array}$
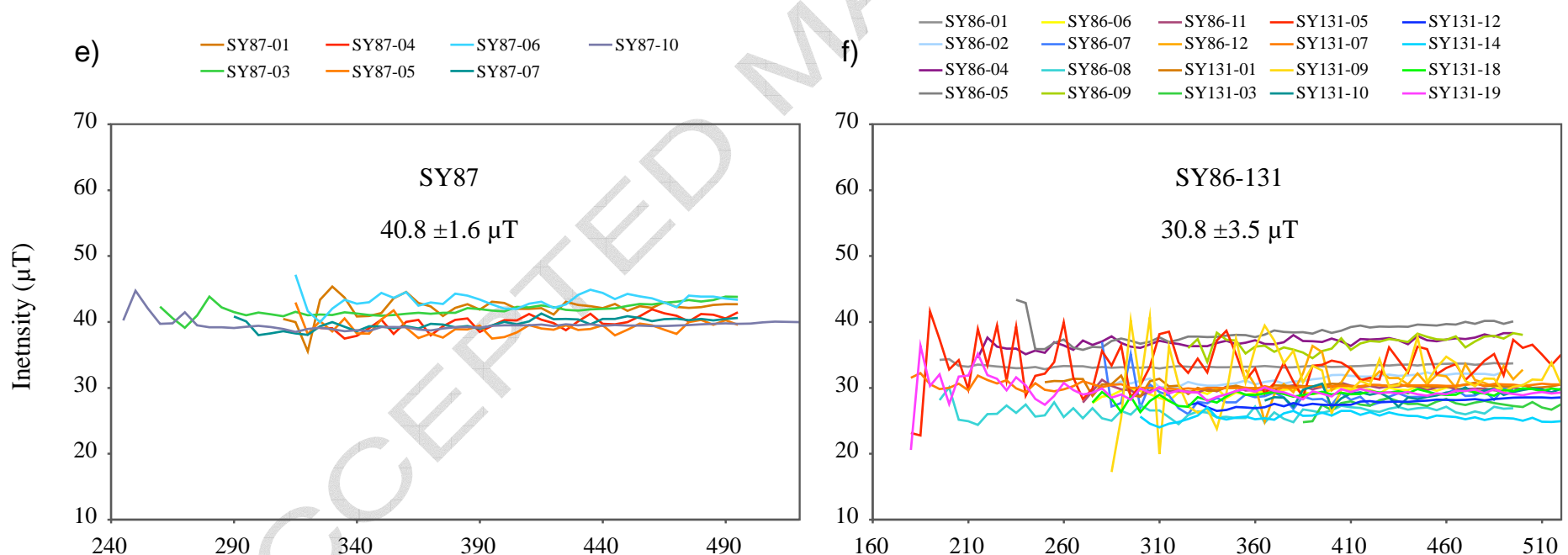

g) $\begin{array}{lllll}\text { - } \mathrm{SY} 84-01 & -\mathrm{SY} 84-03 & -\mathrm{SY} 84-05 & -\mathrm{SY} 84-07 & -\mathrm{SY} 84-10 \\ -\mathrm{SY} 84-02 & -\mathrm{SY} 84-04 & -\mathrm{SY} 84-06 & -\mathrm{SY} 84-08 & -\mathrm{SY} 84-11\end{array}$
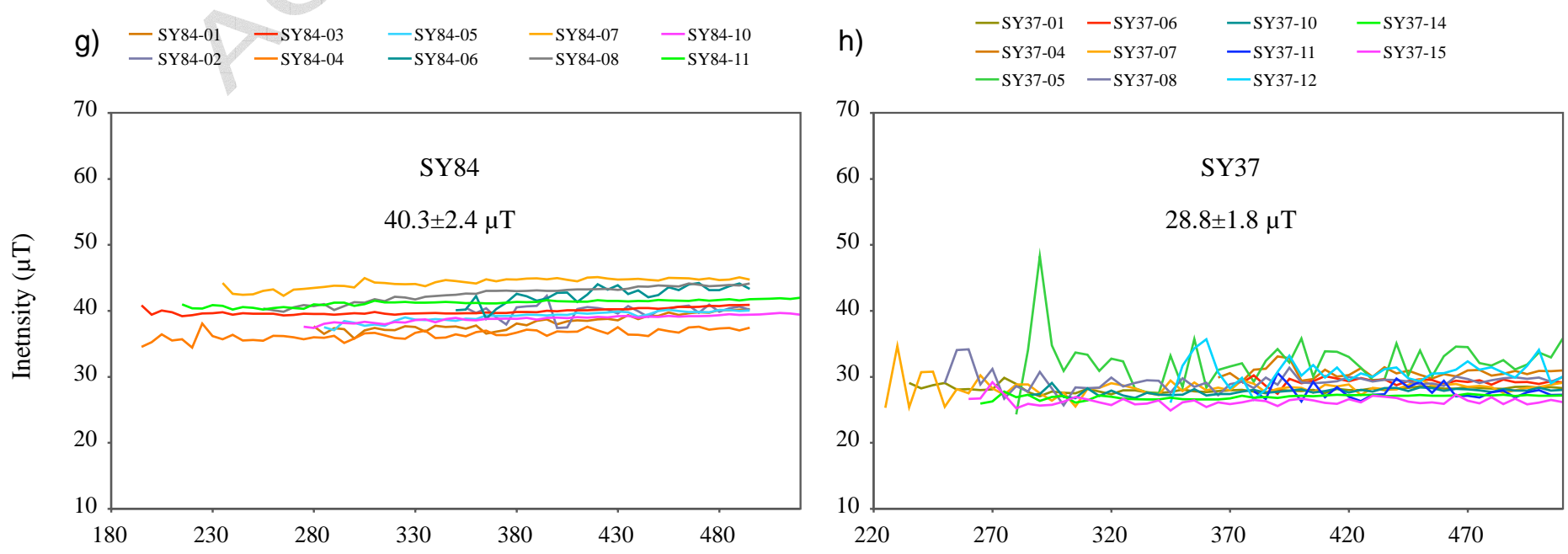

Temperature $\left({ }^{\circ} \mathrm{C}\right)$

Temperature $\left({ }^{\circ} \mathrm{C}\right)$

Figure 5 


\section{ACCEPTED MANUSCRIPT}

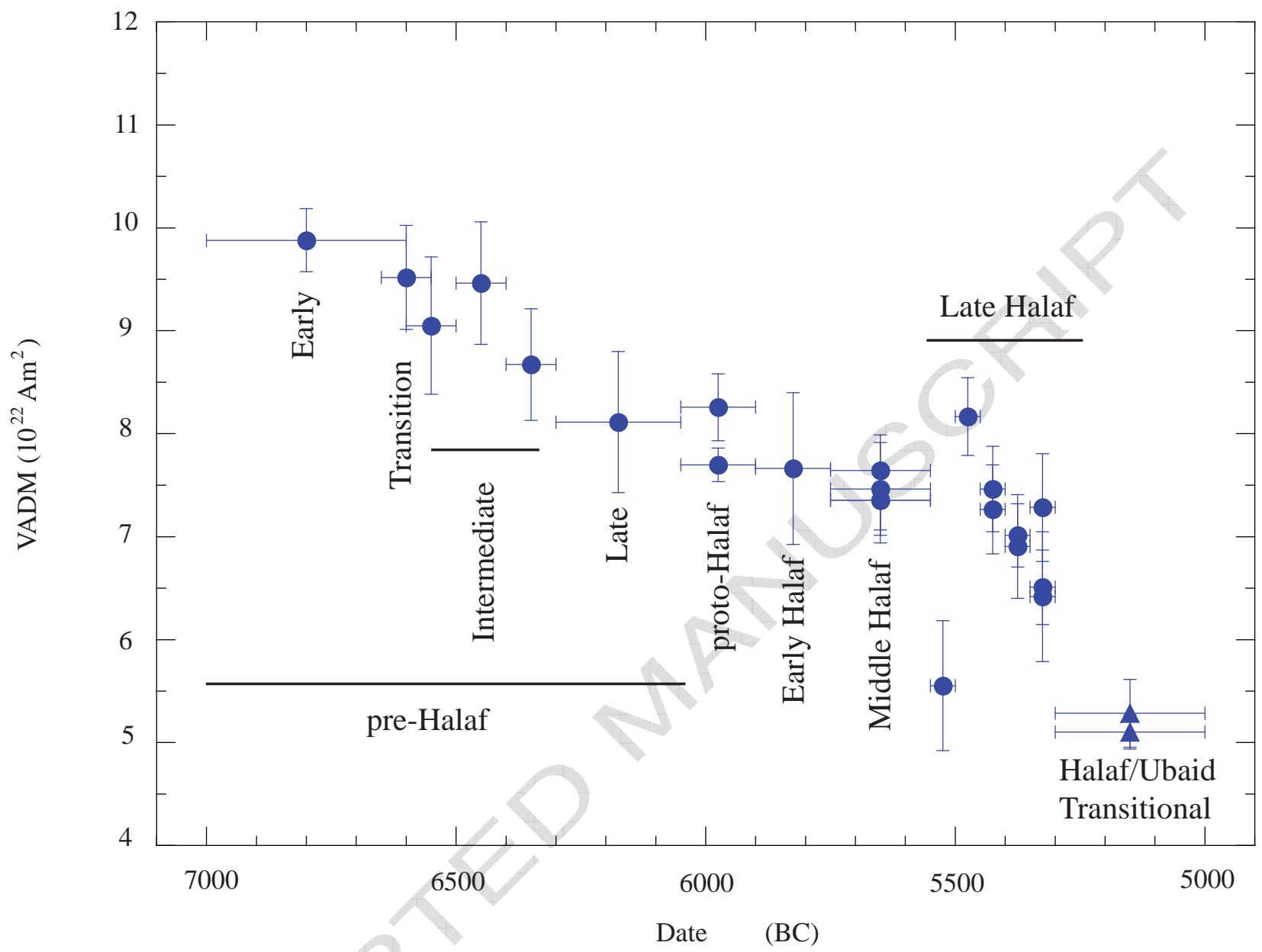

Figure 6 

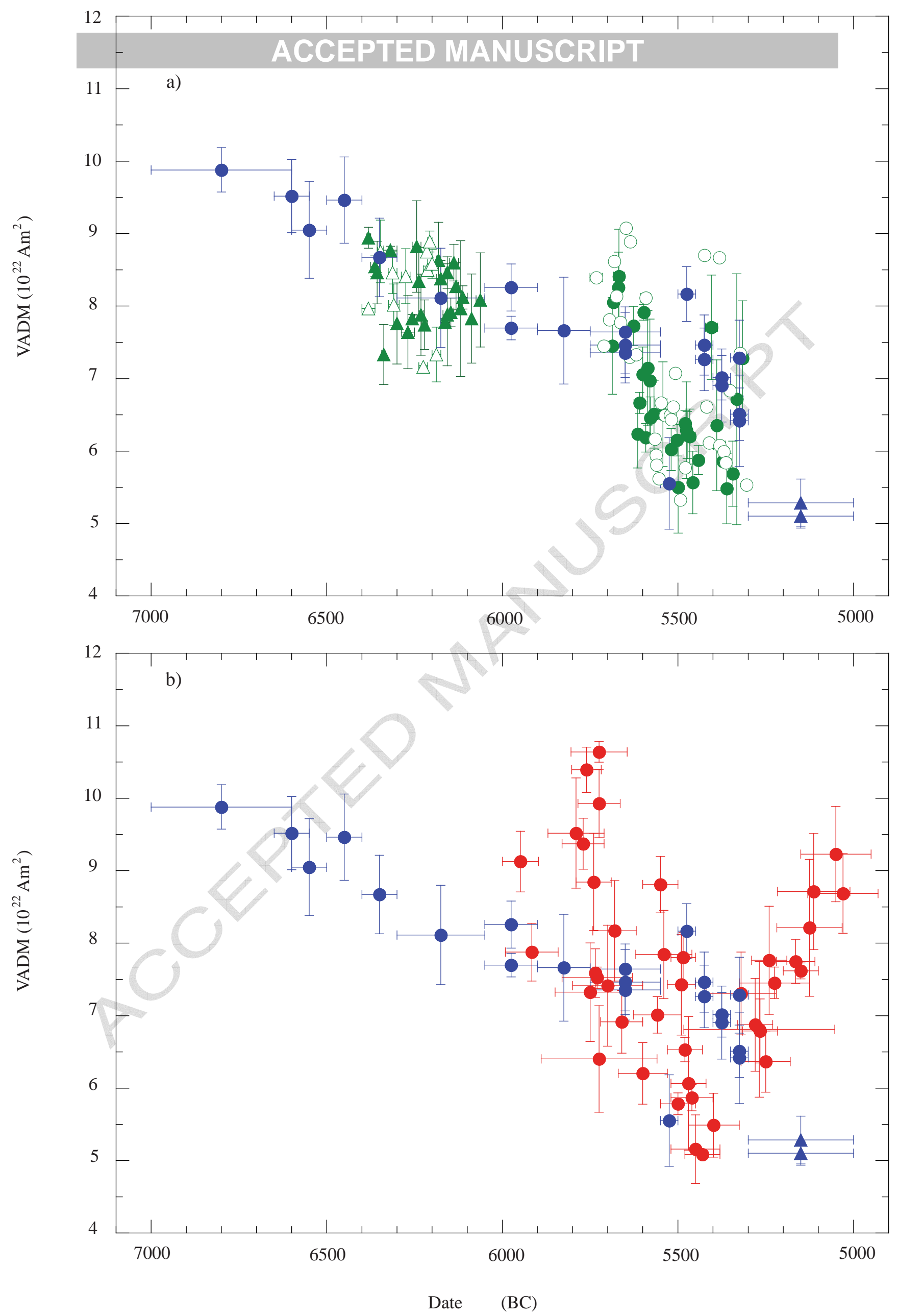

Figure 7 


\section{Figure 8}
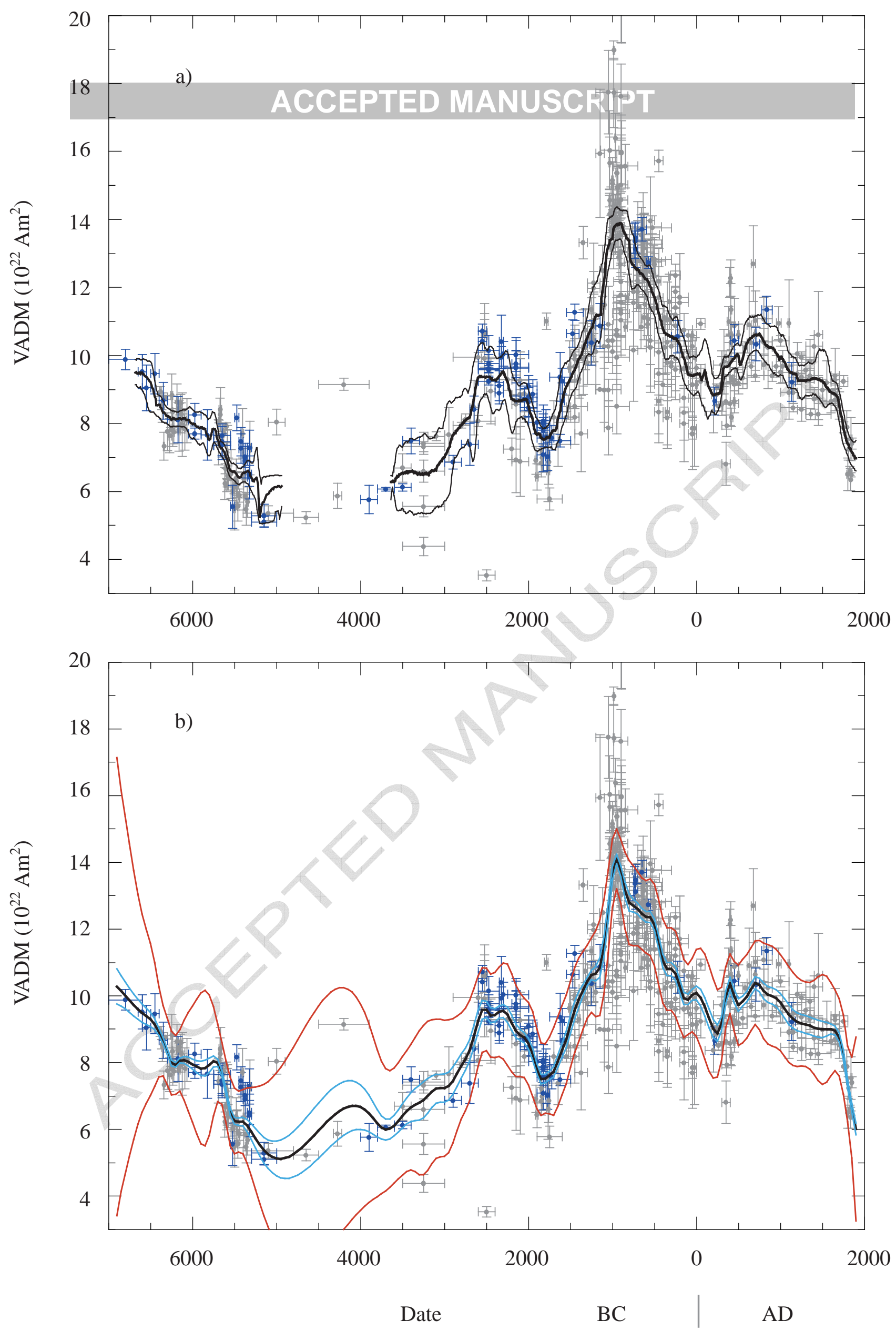

Figure 8 

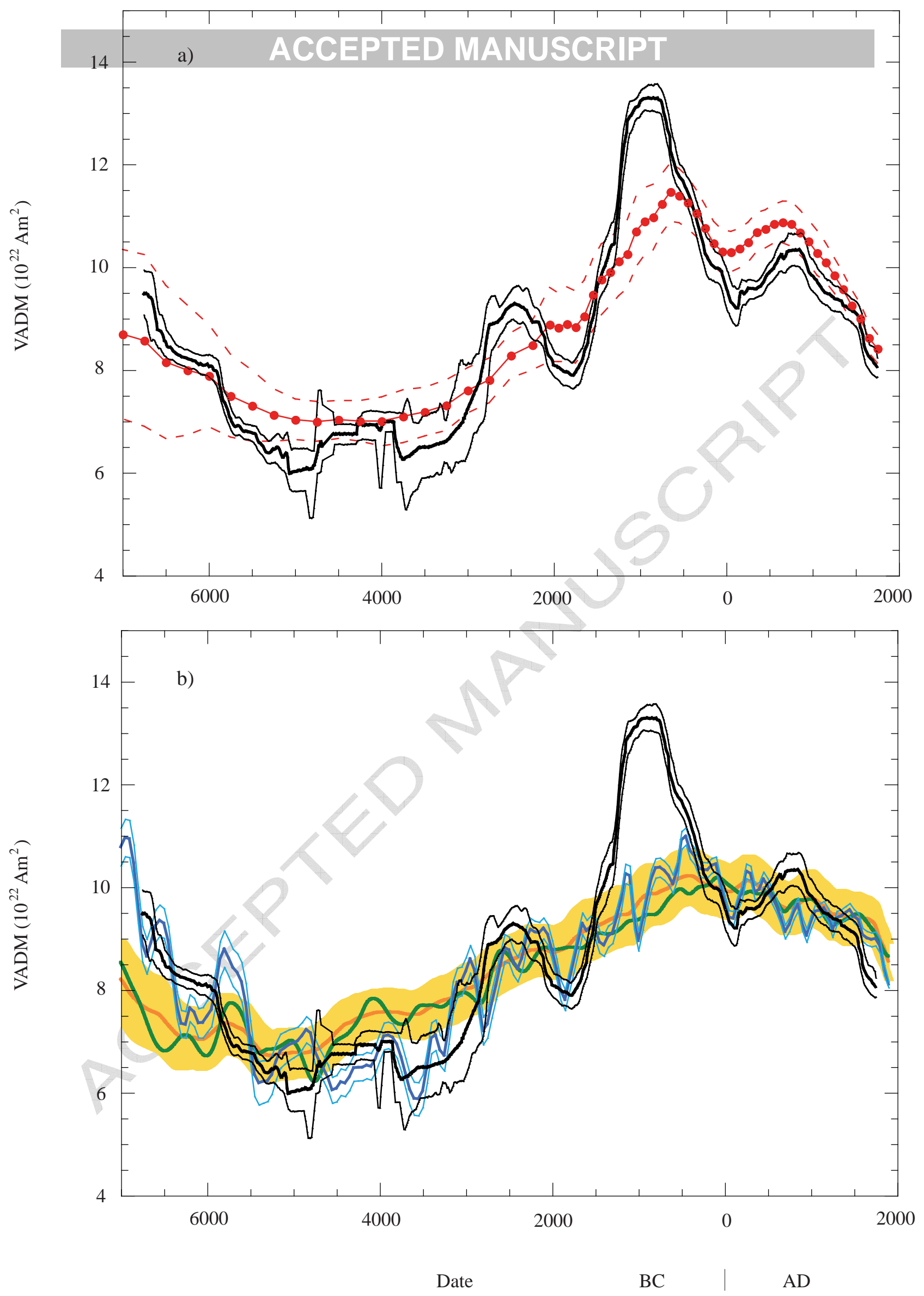

Figure 9 


\begin{tabular}{|c|c|c|c|c|c|c|}
\hline Pottery Group & Archeological Period & $\begin{array}{l}\text { Relative chronology } \\
\text { (Tell Halula) }\end{array}$ & Archeological reference & Age (BCE) & $\begin{array}{c}\text { Intensity } \\
(\mu T)\end{array}$ & $\begin{array}{c}\mathbf{N} \text { frag. } \\
\text { (n } \\
\text { spec.) }\end{array}$ \\
\hline & & \multicolumn{5}{|c|}{ ACCEPTED MANUSCRIPT } \\
\hline SY127 & Early Pre-Halaf & Phase I & jector 2 , square $G$, peat ElC & $6800 \pm 200$ & $54.8 \pm 1.7$ & $3(9)$ \\
\hline SY125 & ransition Early-Intermediate Pre-Halé & Phase I/II & Sector 2, square I, A25 & $6600 \pm 50$ & $52.8 \pm 2.8$ & $2(6)$ \\
\hline SY98-128 & Intermediate Pre-Halaf & Phase II -early phase & Sector SS14-Y, A6 & $6650 \pm 50 *$ & $50.2 \pm 3.7$ & $12(12)$ \\
\hline SY97-129 & Intermediate Pre-Halaf & Phase II -interm. Phase & Sector SS14-Y, A5a & $6450 \pm 50 *$ & $52.5 \pm 3.3$ & $17(17)$ \\
\hline SY96-140 & Intermediate Pre-Halaf & Phase II -late phase & Sector SS14-Y, A3C & $6350 \pm 50 *$ & $48.1 \pm 3.0$ & $13(13)$ \\
\hline SY130 & Late Pre-Halaf & Phase III & Sector 49, A9a, E25 & $6175 \pm 125$ & $45.0 \pm 3.8$ & $7(7)$ \\
\hline SY94-137 & Proto-Halaf & Phase IV & Sector 44/3, A23, E27 & $5975 \pm 75$ & $45.8 \pm 1.8$ & $17(17)$ \\
\hline SY95 & Proto-Halaf & Phase VI & Sector $40, \mathrm{~A} 10$ & $5975 \pm 75$ & $42.7 \pm 0.9$ & $5(14)$ \\
\hline SY91 & Early Halaf & Phase $\mathrm{V}$ & Sector $44 / 4$ & $5825 \pm 75$ & $42.5 \pm 4.1$ & $9(9)$ \\
\hline SY87 & Middle Halaf & Phase VI & Sector 45 , peat E5 & $5650 \pm 100$ & $40.8 \pm 1.6$ & $7(7)$ \\
\hline SY88 & Middle Halaf & Phase VI & Sector 45 , peat E9 & $5650 \pm 100$ & $42.4 \pm 1.5$ & $7(7)$ \\
\hline SY89 & Middle Halaf & Phase VI & Sector 45 , peat E1 & $5650 \pm 100$ & $40.8 \pm 1.9$ & $8(8)$ \\
\hline SY90 & Middle Halaf & Phase VI & Sector 45 , peat E3 & $5650 \pm 100$ & $41.4 \pm 2.9$ & $8(8)$ \\
\hline SY86-131 & Late Halaf & Phase VII -early phase & Sector 49, A5 & $5525 \pm 25^{*}$ & $30.8 \pm 3.5$ & $20(20)$ \\
\hline SY135 & Late Halaf & Phase VII -interm./early Phase & Sector $49, A 1 \mathrm{~g}$ & $5475 \pm 25 *$ & $45.3 \pm 2.1$ & $11(11)$ \\
\hline SY84 & Late Halaf & Phase VII -interm./interm Phase & Sector 49 , Alc & $5425 \pm 25 *$ & $40.3 \pm 2.4$ & $10(10)$ \\
\hline SY138 & Late Halaf & Phase VII -interm./interm. Phase & Sector 49, Alc, E8 & $5425 \pm 25 *$ & $41.4 \pm 2.3$ & $11(11)$ \\
\hline SY82 & Late Halaf & Phase VII -interm./late Phase & Sector $49, \mathrm{~A} 7$ & $5375 \pm 25 *$ & $38.3 \pm 2.8$ & $7(7)$ \\
\hline SY83-136 & Late Halaf & Phase VII -interm./late phase & Sector 49, Alb & $5375 \pm 25 *$ & $38.9 \pm 1.7$ & $13(13)$ \\
\hline SY80 & Late Halaf & Phase VII -late phase & Sector 49 , A7d, peat 24 & $5325 \pm 25^{*}$ & $35.6 \pm 3.5$ & $8(8)$ \\
\hline SY81 & Late Halaf & Phase VII -late phase & Sector $49, A 7 c$, peat 32 & $5325 \pm 25 *$ & $36.1 \pm 2.0$ & $6(6)$ \\
\hline SY132 & Late Halaf & Phase VII -late phase & Sector 49, A7a, E21 & $5325 \pm 25 *$ & $40.4 \pm 2.9$ & $8(8)$ \\
\hline SY37 & Halaf-Ubaid Transitional & - & Locus $\mathrm{K} 171 \mathrm{I} / 2$, layer E2 & $5150 \pm 150$ & $28.8 \pm 1.8$ & $11(11)$ \\
\hline SY38 & Halaf-Ubaid Transitional & - & Locus K171 I, floor E7 & $5150 \pm 150$ & $27.8 \pm 0.9$ & $5(15)$ \\
\hline
\end{tabular}

Table 1 
848 New archeomagnetic intensity data from two Syrian Late Neolithic archeological sites 849

850 We recover the regional geomagnetic intensity variations between $\sim 7000 \mathrm{BC}$ and $851 \sim 5000 \mathrm{BC}$

852

853 A 9000-years long archeointensity variation curve is constructed for the Middle East 854

855 We constrain the variations in the dipole field moment over most of the Holocene 856

857 